\title{
NO HAY BUENA FE SIN INTERÉS: LA BUENA FE PROCESAL Y LOS DEBERES DE VERACIDAD, COMPLETITUD Y COLABORACIÓN
}

\author{
Iván Hunter Ampuero*
}

\begin{abstract}
RESUMEN
En el presente trabajo se pretende abordar la legitimidad del deber de veracidad, completitud y colaboración en el proceso civil como deberes jurídicos derivados de la buena fe procesal, junto con delinear los aspectos más relevantes de dicha noción. El autor intenta justificar por qué no resulta conveniente para un proceso civil respetuoso de los derechos e intereses de los ciudadanos establecer deberes positivos de conducta amparados en la buena fe procesal. Por último, concluye que el verdadero sitial de la buena fe procesal supone ser sustituida más bien por la probibición de actuaciones de mala fe, descartando, por ende, la imposición a los litigantes de deberes positivos de actuación.
\end{abstract}

BUENA FE PROCESAL - DEBER DE VERACIDAD - DERECHO A DEFENSA

\author{
There isn't good faith without interests: good faith in legal \\ procedure and the duties of veracity, completeness and collaboration
}

Abstract

This paper is intended to approach the legitimacy of the duty of veracity, completeness and collaboration in the civil procedure, as legal duties derived from procedural good faith, together with delineating the most relevant aspects of this notion. The author intends to justify why it isn't convenient to establish positive duties of conduct for a civil procedure that is respectful of rights and interests of citizens under procedural good faith. Finally, it is concluded that the true throne of procedural good faith is supposed to be substituted by the probibition of bad faith performances, discarding the imposition of positive performance duties for litigators.

PROCEDURAL GOOD FAITH - DUTY OF VERACITY - RIGHT TO DEFENSE

* Abogado, Magíster en Derecho, Profesor Derecho Procesal, Universidad Austral de Chile, Valdivia, ivanhunter@uach.cl. Artículo recibido el 28 de agosto de 2008 y aceptado para su publicación por el Comité Editorial el 24 de octubre de 2008. 


\section{INTRODUCCIÓN}

$\mathrm{U}$ no de los institutos donde es legítimo verter las convicciones propias es la buena fe procesal, y no sólo en sus aspectos configurativos (que responden a la pregunta de qué es la buena fe procesal), sino también en las derivaciones conexas al establecimiento de esta máxima de actuación (que responde a la pregunta de las consecuencias que para el sistema procesal tiene el exigir a los litigantes comportarse de buena fe). El estudio doctrinario de la buena fe procesal ha sido en gran parte ignorado por el foro, aun cuando pretende alzarse en un principio inspirador del nuevo proceso civil. ${ }^{1}$

En este trabajo pretendo enfrentar dos interrogantes acerca del rol de la buena fe: primero, verificar si a partir de una cláusula general de comportamiento de buena fe procesal es posible extraer y fundamentar ciertos deberes positivos, especialmente el deber de veracidad y completitud en las alegaciones, y el de cooperación o colaboración. Enseguida, plantear la posibilidad de sustituir el concepto de buena fe procesal por el de prohibición de actuaciones de mala fe.

Como hipótesis preliminar diré que el ordenamiento jurídico no puede exigir a los litigantes que se conduzcan de buena fe, sino solamente puede prohibir las conductas de mala fe y sancionarlas. En consecuencia, no sería legítimo generar deberes positivos de actuación fundados en la buena fe, pero sí deberes negativos o de abstención, enmarcados dentro de la proscripción de mala fe procesal. Por lo tanto, los deberes de veracidad y completitud en las alegaciones, así como el de colaboración, no podrían tener cabida en un proceso que se considere respetuoso de los derechos e intereses legítimos del ciudadano como también de las garantías de que viene revestida la actividad jurisdiccional.

\section{LA DIFÍ́CIL TAREA DE DELIMITAR EL CONCEPTO DE BUENA FE PROCESAL}

Nada nuevo digo cuando afirmo que el concepto de buena fe es un concepto jurídico indeterminado. Tampoco innovo cuando digo que se trata de una regla con la que se pretende introducir reglas morales, éticas y sociales al ámbito de las relaciones reguladas por el Derecho. Estas características ponen a la buena fe en una constante tensión con la seguridad jurídica. El inconveniente más grave, por su enorme repercusión práctica, es que enfrenta al intérprete a la necesidad de dotar a la regla de un contenido lo más concreto y preciso posible, para no hacer de tal noción un concepto jurídicamente irrelevante. La difícil tarea de delimitación de contenido sólo permitirá al operador arribar a "meras aproximaciones conceptuales"2 y no a un contenido hermético.

La doctrina en general ha mantenido cierta uniformidad en los elementos básicos que conforman el concepto. Así, Picó i Junoy la ha definido como "aquella conducta

${ }^{1}$ Cfr. Maturana, C., "Los principios que deben regir un nuevo proceso civil en Chile", en Hacia una Nueva Justicia Civil, Boletín Jurídico del Ministerio de Justicia, No 7, año 4, 2005, p. 12.

${ }^{2}$ Picó i Junoy, J., El principio de la buena fe procesal, Bosch Editor, Barcelona, 2003, p. 67. 
exigible a toda persona, en el marco de un proceso, por ser socialmente admitida como correcta". ${ }^{3}$ Lozano-Higuero ha dicho, por su parte, que por el principio de probidad debe entenderse aquel "conjunto de reglas, standards o criterios de conducta, de carácter ético, social y deontológico, a que deben adaptar su comportamiento los sujetos procesales (partes, profesionales causídicos, juez, secretario, personal auxiliar y secretarial, peritos, testigos, etc.) en el curso del proceso y todo acto procesalmente relevante". ${ }^{4}$

Todas las definiciones son perfectamente válidas y permiten verificar el claro contenido ético, moral y axiológico que implica apelar a la buena fe procesal. ${ }^{5}$ Sin embargo, en una sociedad pluralista y democrática resulta ciertamente difícil alcanzar unanimidad en los valores o códigos éticos entre uno y otro individuo. Por consiguiente, me parece que hay que ser cuidadosos cuando al integrar el contenido del concepto se echa mano a valoraciones subjetivas y personales, y no a los que suponen gobernar en una sociedad determinada.

\section{LA BUENA FE EN EL ORDENAMIENTO JURÍDICO NACIONAL}

La buena fe es un concepto que hasta el momento permanece algo ajeno al proceso civil. Ha sido principalmente el Derecho Civil patrimonial el campo más fecundo para la actuación de la buena fe, tanto en su vertiente objetiva -Art. 1546 de Código Civilcomo en la subjetiva -Art. 702 del Código Civil-.

En el campo del proceso civil patrimonial, sin embargo, no hay una norma general que imponga a las partes la necesidad de adecuar su conducta a la buena fe procesal. Solamente se encuentran algunas normas que hacen expresa referencia a la mala fe (entre otros, el Art. 88 del Código de Procedimiento Civil) y otras donde la idea de la buena o mala fe parece figurar implícita. ${ }^{6}$ En materia procesal civil se encuentra más de algún estudio que la aborda desde la teoría de los actos propios, ${ }^{7}$ y otro más reciente

${ }^{3}$ Ibid., p. 69. La jurisprudencia del Tribunal Supremo Español, en idéntica forma, entiende que la buena fe procesal está ligada al ejercicio de los derechos con sujeción a imperativos éticos exigidos socialmente como la honradez y la lealtad. Vid., entre otras: STS, 1 de marzo de 2001 (RA 2588); STS, 22 de febrero de 2001 (RA 2609); STS, 29 de febrero de 2000 (RA 812).

${ }^{4}$ Lozano-Higuero, M., "La probidad en el nuevo proceso civil (Respecto a las reglas de la buena fe procesal. Multas por su incumplimiento)", en Revista Vasca de Derecho Procesal y Arbitraje, tomo XIV, 2002, p. 326.

${ }^{5}$ Vid., Jiménez, S., "La buena fe: perspectiva doctrinal, legal y jurisprudencial. Examen del artículo 247 de la vigente Ley de Enjuiciamiento Civil”, en Revista Jurídica Española de doctrina, jurisprudencia y bibliografía, La Ley, $\mathrm{N}^{\circ}$ 4, 2003, p. 1561.

${ }^{6}$ No es mi intención repetir aquí lo que ya está escrito -y además muy bien- en otro lado. Sobre la buena fe procesal en el ordenamiento chileno, véase: Carretta, F., "Deberes procesales de las partes en el proceso civil chileno: referencia a la buena fe procesal y al deber de coherencia”, en Revista de Derecho Universidad Austral de Chile, Vol. XXI, No 1, julio, 2008, pp. 116 a 120.

${ }^{7}$ Vid., Romero Seguel, A., "Comentario a la sentencia de la Corte de Suprema de 9 de mayo de 2001. El principio de la buena fe procesal y su desarrollo en la propia jurisprudencia, a la luz de la doctrina de los actos propios", en Revista Chilena de Derecho, Vol. 30, N 1, 2003, pp. 167 a 172. 
que intenta justificar la existencia de deberes procesales, en especial el de coherencia, a partir de la buena fe. ${ }^{8}$

\section{LA BUENA FE Y LOS DEBERES PROCESALES}

Cierta parte de la doctrina nacional y comparada ha declarado decididamente que la buena fe es una herramienta que permite originar deberes al interior del proceso 9 , exigiendo directamente una conducta acorde a ella. ${ }^{10}$

Por su parte, el Proyecto de Reforma al Proceso Civil chileno -en adelante simplemente el Proyecto- incluye en el Art. 8, denominado de la "Buena fe procesal", una norma que prescribe la sumisión de la conducta de las partes la lealtad y buena fe procesal. No se precisa, en cambio, el deber general de veracidad y completitud en las alegaciones, como tampoco el deber de colaboración. ${ }^{11}$

El problema radica en determinar si la fórmula normativa de actuación conforme a la buena fe procesal puede extenderse a las alegaciones fácticas de las partes. Este problema forma parte de uno más general acerca de la posibilidad de derivar desde una cláusula general de buena fe, vía doctrinal o jurisprudencial, algunos deberes positivos de actuación.

La complicación se genera principalmente en los ordenamientos donde no está sancionado de forma expresa el deber de decir la verdad y de ser íntegros en las alegaciones de hecho. No sucede lo mismo, en cambio, en los ordenamientos que han consagrado de modo inequívoco tales deberes, aun cuando no dispongan una determinada consecuencia ante su incumplimiento. Tal es el caso de la experiencia alemana, donde el Art. 138 de la ZPO consagra el deber de las partes de ser veraces. En el mismo supuesto se encuentra el ordenamiento austriaco con la Ordenanza Procesal de Klein de 1895, que en el Art. 178 mantiene en vigencia el principio de veracidad y completitud en las narraciones de los hechos.

Al igual que en el Proyecto, tanto el proceso civil italiano como el español carecen de disposiciones expresas donde fundar el deber de veracidad, completitud y el de colaboración. ${ }^{12}$ En ambos casos la doctrina ha intentado extraer del deber genérico

${ }^{8}$ Vid., Carretta, F., "Deberes procesales de las partes en el proceso civil chileno: referencia a la buena fe procesal y al deber de coherencia”, op. cit., pp. 101 a 127.

${ }^{9}$ Ibíd., p. 118, quien formula expresamente que "impuesta la creación de una herramienta adecuada para el efectivo resguardo de la buena fe, se originan deberes al interior del proceso”.

${ }^{10}$ Cfr. Jiménez S., "La buena fe: perspectiva doctrinal, legal y jurisprudencial. Examen del artículo 247 de la vigente Ley de Enjuiciamiento Civil”, op. cit., p. 1562.

${ }^{11}$ Sobre este seudodeber de colaboración de las partes en el proceso civil puede verse: Grasso, E., "La collaborazione nel processo civile", en Rivista di Diritto Processuale, Vol. XXI, 1996, pp. 580 y siguientes. Cfr., además, Carretta, F., "Deberes procesales de las partes en el proceso civil chileno: referencia a la buena fe procesal y al deber de coherencia”, op. cit., p. 107, que a propósito de la contestación ficta de la demanda y la desobediencia del demandado, habla de un "principio de colaboración", que no justifica en qué se basa. Hago la prevención si es que el autor no ha tomado tal deber en el sentido que se precisa en este trabajo.

${ }^{12}$ Para el estado de la discusión en el proceso italiano. Vid., Calogero, G., "Probità, lealtà, veracità nel processo civile”, en Rivista di Diritto Processuale Civile, Vol. XVI, parte I, 1939, pp. 129 a 139. 
de actuación conforme a la buena $\mathrm{fe}^{13}$ un deber específico de ser veraz e íntegro en la narración de los hechos, como el colaborar con la acción de la justicia para la obtención de la sentencia justa.

Así, para Marchetti si la obligación de lealtad o probidad no comprendiera la de ser veraz resultaría escasamente inteligible sobre el plano de la concreta realidad procesal, por ende, el deber de veracidad constituye la primera y más elemental forma de lealtad. ${ }^{14}$ Cappelletti, por su parte, agrega que no parece posible, sin querer cerrar los ojos ante el Art. 88 del Codice de Procedura Civile italiano, negar un deber de decir la verdad, o sea, afirmar un poder de reticencia o de mentira de la parte en perjuicio del adversario. ${ }^{15}$ Micheli, en idéntica forma, sostiene que el deber de veracidad es un aspecto del deber de buena fe procesal que no estaría en absoluto en contraste con la existencia de poderes procesales reconocidos a las partes. ${ }^{16}$

En el derecho español la situación no cambia en lo absoluto. Picó i Junoy señala que la aplicación del deber de veracidad deriva de la existencia de la buena fe procesal como pauta de conducta que deben acatar los litigantes, y ello porque difícilmente puede calificarse un acto de buena fe cuando se fundamenta en la mentira, engaño o falseamiento de la verdad. ${ }^{17}$ Agrega el autor que la defensa de una parte no puede basarse en perjudicar el derecho a defensa de la otra o en la inducción a error del órgano jurisdiccional, impidiendo o dificultando que pueda ofrecer una efectiva tutela de los intereses en conflicto. ${ }^{18}$ Prieto Castro, aun sin vincular de modo expreso ambos deberes, sostiene que la libertad de la conducta de las partes no puede extenderse al extremo de lesionar la buena fe y la ética procesal, dado que si bien el proceso es una lucha éste ha de ser leal y guiado por la verdad. ${ }^{19}$ En el mismo sentido opinan Montero Aroca y Lozano, no obstante, dirigen una mirada crítica al instituto en cuestión. ${ }^{20}$

${ }^{13}$ En el caso italiano el Art. 88 inciso $1^{\circ}$ del Codice de Procedura Civile dispone: "Le parti e i loro difensori hanno il dovere di comportarsi in giudizio con lealtà e probitá". Por su parte, el Art. 247 regla $1^{\text {a }}$ de la Ley de Enjuiciamiento Civil española del 2000, dispone: "Los intervinientes en todo tipo de procesos deberán ajustarse en sus actuaciones a las reglas de la buena fe".

${ }^{14}$ Cfr., Marchetti, C., "Dolo revocatorio e falsa alegazione", en Rivista di Diritto Processuale, Vol. XV, 1960, p. 427.

${ }^{15}$ Cfr., Cappelletti, M., El testimonio de la parte en el sistema de oralidad. Contribución a la teoría de la utilización probatoria del saber de las partes en el proceso civil. Primera parte, traducción de Tomás Banzhaf, Librería Editora Platense, La Plata, 2002, p. 364.

${ }^{16}$ Cfr., Micheli, G. A., La carga de la prueba, traducción de Santiago Sentis Melendo, Editorial Temis, Bogotá, 2004, pp. 151 y 152.

${ }^{17}$ Vid., Picó i Junoy, J., El principio de la buena fe procesal, op. cit., pp. 133 y 134. En el mismo sentido, aunque sin una explicación: Gimeno Sendra, V., "Análisis crítico de la Ley de Enjuiciamiento Civil”, en Revista Jurídica Española de Doctrina, Jurisprudencia y Bibliografía, No 2, 2007, p. 1893.

${ }^{18}$ Cfr. Picó i Junoy, J., El principio de la buena fe procesal, op. cit., pp. 133 y 134.

${ }^{19}$ Cfr. Prieto Castro, L., "Ética procesal. Valoración de la conducta de las partes", en Estudios y comentarios para la teoría y la práctica del proceso civil, Vol. I, Editorial Reus, Madrid, 1950, pp. 140 y 141.

${ }^{20}$ Cfr. Lozano-Higuero, M., "La buena fe procesal: consideraciones doctrinales y jurisprudenciales”, en El abuso del proceso: mala fe y fraude de ley procesal, Consejo General del Poder Judicial, Madrid, 2006, p. 53, y ahí mismo: Montero Aroca, J. "Ideología y proceso civil. Su reflejo en la buena fe procesal”, p. 281. 
En Chile cierta parte de la doctrina ha seguido muy de cerca los postulados del derecho comparado. Se ha dicho al efecto que el principio de aportación de parte debería admitir en el proceso civil una limitación emparentada con el deber de actuar de buena fe, principio de acuerdo al cual "las partes deben formular sus declaraciones sobre las circunstancias fácticas íntegramente y de acuerdo a la realidad de los hechos". ${ }^{21}$ En consecuencia, para esta posición doctrinal el deber de veracidad y completitud en la exposición de los hechos tendría una cabida dentro de la amplitud normativa del Art. 8 del Proyecto.

Para otra parte de la doctrina comparada no puede desprenderse de la cláusula general de actuación conforme a la buena fe procesal un deber de veracidad y completitud de las alegaciones fácticas. ${ }^{22} \mathrm{Al}$ efecto, se ha dicho que desde el momento en que el sistema eligió no atribuir credibilidad a la declaración de la parte por la obvia razón de que podría mentir, no se ve cómo puede pretender el sistema que la parte mantenga, sin embargo, la obligación de decir la verdad. ${ }^{23}$ De igual forma, un semejante deber estaría en contraste con la distribución de la carga de la prueba, en el sentido de que la parte al tener que declarar aquellas circunstancias que le son desfavorables, estaría acreditando aspectos que favorecen a la otra parte y que son de su exclusiva carga probar. ${ }^{24}$ Por último, se agrega que si ambas partes cumplen efectivamente con el deber de veracidad los hechos históricos atingentes a la controversia emergerían en modo conforme a la narración de los litigantes, por lo que no habría necesidad de un control formal de la verdad a través de los medios de prueba. ${ }^{25}$

De igual forma, el deber de colaboración -cuya manifestación más evidente es la de acompañar al proceso todos los medios de prueba al alcance de la parte- tiene un claro fundamento en el deber de actuar conforme a la buena fe procesal. Explica la doctrina que el deber de colaboración se funda en la buena fe procesal y precisa un esfuerzo conjunto de las partes para buscar con el juez la justa y pronta solución del litigio. ${ }^{26}$ Así, los litigantes al tener que adecuar su conducta a criterios de rectitud y honradez socialmente exigibles tendrían el deber de aportar al proceso los medios de prueba necesarios para

${ }^{21}$ Núñez, R., "Crónica sobre la reforma del sistema procesal civil chileno (Fundamentos, historia y principios) en Revista de Estudios de la Justicia, No 6, 2005, p. 181. No es del caso tratar pero a mi juicio el principio de aportación de parte no sufre ninguna alteración con la imposición de este deber, a menos que quiera relacionarse con una manifestación de la estructura dialéctica del proceso, cuestión que no parece estar refrendada por el autor.

${ }^{22}$ Vid., Scarselli, G., "Lealtà e probità degli atti processuali”, en Rivista Trimestrale di Diritto e Procedura Civile, N ${ }^{\circ}$ 1, año LII, 1998, p. 114; Calamandrei, P., "Il processo come gioco", en Rivista di Diritto Processuale, Vol. V, parte I, 1950, pp. 29 a 33, y Calogero, G., "Probità, lealtà, veracità nel processo civile", op. cit., pp. 129 a 153 .

${ }^{23} \mathrm{Vid}$., Scarselli, G., "Lealtà e probità degli atti processuali", op. cit., 114.

${ }^{24}$ Ibid., p. 115.

${ }^{25}$ Ibid.

26 Vid., Vallote, D., “Abuso del proceso por las partes, presupuestos generales”, en XXI Congreso Nacional de Derecho Procesal, Tomo I, Universidad Católica del Cuyo, San Juan, 2001, pp. 274 y 275. En casi idéntico sentido: Vallejos, J., "El abuso del proceso en materia probatoria", en XXI Congreso Nacional de Derecho Procesal, Tomo I, Universidad Católica del Cuyo, San Juan, 2001, pp. 737. 
cumplir con los estándares que demanda la colaboración con la justicia. Nada más distante con un comportamiento leal es el esconder, negar o silenciar un medio de prueba que puede ser fundamental para la correcta adjudicación del juicio.

No obstante la fuerte disputa doctrinal que todavía se mantiene viva, no cabe duda que un deber de veracidad y completitud como el de colaboración pueden ser perfectamente enmarcados dentro de la amplitud del concepto de buena fe procesal. Decir la verdad sin omitir detalle relevante es una conducta que en el marco de un conflicto judicial es considerada como social y éticamente correcta. Actúa lealmente quien narra los hechos de modo verídico y completo, así como el litigante que introduce al proceso todos los elementos de convicción necesarios para la dictación de una sentencia justa y colabora con el fin del proceso. ${ }^{27}$

Otra cuestión, desde luego, es admitir la conveniencia de derivar o incluir estos deberes dentro del proceso civil o de sostener su compatibilidad con el derecho a defensa y el principio dispositivo. Son precisamente estos extremos los que deberían colmar la preocupación de la doctrina del proceso civil, por ser una de las consecuencias más relevantes al momento de adoptar a la buena fe procesal como noción generadora de deberes procesales. Una teoría que pretenda fundar en forma general deberes endoprocesales sin considerar al proceso como un fenómeno sistémico, conexo e interdependiente, corre el peligro de poner en jaque las garantías constitucionalmente consagradas.

Para cerrar este acápite baste precisar el contenido del deber de veracidad y completitud en la narración de los hechos. Según la doctrina, el deber de veracidad consiste en no alegar como existentes hechos que se saben inexistentes $y$, al mismo tiempo, no negar hechos que se sabe que son verdaderos. ${ }^{28}$ Por su parte, el deber de completitud consistiría en alegar todos los hechos relevantes para la correcta resolución del conflicto sin omitir dato alguno que caiga bajo el dominio de la parte. Este deber se viola simplemente omitiendo decir cualquier hecho que forme parte del patrimonio cognoscitivo del litigante. ${ }^{29}$

Si bien desde el punto de vista teórico ambos deberes resultan perfectamente separables, no lo son en su virtualidad práctica: como lo indica la doctrina, el decir la verdad no puede dejar de implicar además un cierto deber de completitud (decir toda la verdad) al menos cuando la reticencia, la reserva mental, equivaldrían práctica y moralmente a la mentira. ${ }^{30}$ Es evidente que si uno de los litigantes ha narrado de manera parcial los

${ }^{27}$ Incluso desde el punto de vista estrictamente semántico hay una estrecha relación entre el actuar lealmente y el ser verídico. En efecto, de acuerdo al Diccionario de la Real Academia Española de la Lengua, ser "leal" en su segunda acepción significa ser fidedigno, verídico y fiel.

${ }^{28}$ Vid., Marchetti, C., "Dolo revocatorio e falsa alegazione", op. cit., p. 430. Como se puede advertir, el deber no es más que una muestra de ética procesal.

${ }^{29}$ Vid., Scarselli, G., "Lealtà e probità degli atti processuali", op. cit., 103. Aun cuando habría que agregar que tiene que tratarse de un hecho jurídicamente relevante, capaz de influir en el resultado del juicio.

${ }^{30}$ Vid., Cappelletti, M., El testimonio de la parte en el sistema de oralidad. Contribución a la teoría de la utilización probatoria del saber de las partes en el proceso civil, op. cit., p. 371 y Grossmann, K., "El deber de veracidad de las partes litigantes en los juicios civiles. Exposición de Derecho Comparado" en Jurisprudencia Argentina, tomo 71, Buenos Aires, 1940, pp. 22 y 23. 
hechos omitiendo unos cuantos que son incompatibles con su posición subjetiva, falta a la verdad y sin "decir mentiras" genera el mismo efecto como si efectivamente las dijera. Estos deberes de veracidad y completitud están en estrecha relación con una pretendida socialización del proceso civil. ${ }^{31}$

\section{LA BUENA FE PROCESAL COMO LÍMITE A LA GARANTÍA CONSTITUCIONAL DEL DERECHO DE DEFENSA}

Nuestro texto constitucional en el Art. $19 \mathrm{~N}^{\circ} 3$ consagra ciertas garantías fundamentales de carácter procesal. Una de estas garantías es el derecho a la defensa jurídica, ${ }^{32}$ considerado una emanación directa de la exigencia constitucional de un procedimiento y una investigación racionales y justos. No parece requerir justificación decir que los derechos, incluso los de carácter fundamental, no tienen pretensiones de absolutividad que los haga inmunes a la imposición de límites. En consecuencia, el derecho de defensa, por su propia naturaleza de derecho fundamental, admitiría la imposición de límites cuando su virtualidad pueda entrar en pugna con otro derecho fundamental.

Si esto es efectivo, el siguiente paso consiste en determinar si la noción de buena fe procesal puede servir de límite a una determinada posición subjetiva reconocida en el máximo nivel normativo dentro del sistema de fuentes, es decir, si es posible limitar el derecho a defensa para lograr comportamientos éticos, leales, honestos y correctos dentro del proceso $^{33}$ o lograr una adecuada justicia.

Como hipótesis preliminar diré que la noción de buena fe procesal no satisface los requerimientos que exige la teoría de los derechos fundamentales para poder limitar un derecho fundamental. Esta respuesta, sin embargo, deja abierta la posibilidad de imponer límites al derecho a defensa para la protección y logro de la tutela judicial efectiva o del derecho de defensa de la contraparte.

31 Vid., Cappelletti, M., "Ideologías en el proceso civil”, en Proceso, Ideología y Sociedad, Ediciones Jurídicas Europa-América, traducción de Santiago Sentis Melendo y Tomás Banzhaf, p. 15 (3-31), y también publicado en Rivista Trimestrale di Diritto e Procedura Civile, No 1, año XVI, 1962, pp. 193 a 219. La connotación socializadora de estos deberes no es, como se pretende, jurídicamente irrelevante. Con ellos se pretende alcanzar una igualdad material de los litigantes dentro del juicio, al suponer que el proceso es un mecanismo para la operatividad de las instituciones sociales y que se destina a poner fin al desequilibrio de la relación jurídico-material.

${ }^{32}$ Como explica la doctrina, el derecho a un debido proceso debe entenderse no sólo como una exigencia constitucional que impone al legislador el deber de regular la función jurisdiccional a través de un proceso, sino además debe agregarse la consagración de una serie de garantías específicas que hagan de ese proceso un mecanismo racional y justo, y dentro de esas garantías debe incluirse el derecho a defensa. Vid., Bordalí, A. "El debido proceso civil", en La constitucionalización del Derecho Chileno, Universidad Austral de Chile, Editorial Jurídica de Chile, 2003, pp. 258.

33 Como indica Cachón, al igual que la noción de buena fe, las garantías constitucionales del proceso tienen un sentido omnicompresivo, por lo que es posible predecir constantes tensiones entre éstas y buena fe procesal. Cfr., Cachón, M., "La buena fe en el proceso civil", en El abuso del proceso: mala fe y fraude de ley procesal, Cuadernos de Derecho Judicial, CGPJ, Madrid, 2006, p. 220 (211 a 249). 
¿Sirve la noción de buena fe procesal como límite a la garantía constitucional de la defensa jurídica? La respuesta ya se había adelantado: no. En efecto, para que un derecho fundamental pueda ser limitado es necesario que tal limitación se encuentre justificada en otros derechos fundamentales o bien en otros bienes o valores constitucionalmente protegidos. ${ }^{34}$ La posible introducción de límites a los derechos fundamentales sólo puede tener lugar en el marco de una habilitación constitucional previa, ya sea implícita o explícita. ${ }^{35}$ Por lo mismo, no vale la invocación de cualquier interés o derecho para limitar un poder subjetivo constitucional, sino únicamente aquel interés que encuentra un acomodo constitucional que lo haga legítimo.

Firme lo anterior, la buena fe se encuentra con dos trabas insalvables: una de carácter formal derivada de su rango simplemente legal dentro del sistema de fuentes y, en consecuencia, de jerarquía inferior a la garantía procesal. ${ }^{36}$ La buena fe no tiene rango constitucional. ${ }^{37}$ No se trata de un valor constitucionalmente protegido y ni siquiera palpita implícita dentro de la amplitud de ciertas cláusulas constitucionales como el bien común o la igualdad.

Por otro lado, se sostiene que el derecho fundamental, como consecuencia de una característica propia, no incluiría conductas que infringieran lo que resulta del principio de buena fe. ${ }^{38}$ Es decir, se trataría de un límite intrínsecamente constitucionalizado, o como lo afirma Moreno García que "la Constitución no ha positivado las libertades con protección extendida en la mala fe". ${ }^{39}$ Esta tesis es inadmisible. Aceptar que la noción de buena fe se

${ }^{34}$ Vid., entre otros: Moreno García, A., "La buena fe y derechos fundamentales en la jurisprudencia del Tribunal Constitucional”, en Revista Española de Derecho Constitucional, No 38, año 13, 1993, p. 269; Aguiar de Luque, L., "Los límites de los derechos fundamentales", en Revista del Centro de Estudios Constitucionales, No 14, 1993, p. 25; Naranjo de la Cruz, R., Los limites de los derechos fundamentales en las relaciones entre particulares: la buena fe, Centro de Estudios Políticos y Constitucionales, Madrid, 2000, p. 75 y Diez-Picazo, L., Sistema de derechos fundamentales, segunda edición, Civitas, Madrid, 2005, p. 117.

${ }^{35}$ Vid., Aguiar de Luque, L., "Los límites de los derechos fundamentales", op. cit., p. 13.

36 Vid., Moreno García, A., "La buena fe y derechos fundamentales en la jurisprudencia del Tribunal Constitucional”, op. cit., p. 268. En contra, Aguiar de Luque, para quien la principal objeción que presenta la buena fe como límite a los derechos fundamentales no deriva de su rango normativo inferior, dado que las normas que postulan la noción de buena fe disfrutan de una presunción de conformidad constitucional y cabe entenderlas subsumidas en la propia lógica constitucional. Cfr., Aguiar de Luque, L., "Los límites de los derechos fundamentales", op. cit., p. 33. Esta última opción no parece salvar la dificultad formal de incluir a la buena fe dentro de los límites posible a un derecho: la conformidad de la buena fe a la Constitución no la eleva a la categoría de norma constitucional por más que forme parte de la propia lógica constitucional.

${ }^{37}$ En contra: Carretta, F., "Deberes procesales de las partes en el proceso civil chileno: referencia a la buena fe procesal y al deber de coherencia”, op. cit., pp. 119, para quien el deber de buena fe procesal encuentra una justificación supralegal en las reglas del debido proceso a la luz del artículo $19 \mathrm{~N}^{\circ} 3$, inciso $5^{\circ}$ del texto constitucional. A mi juicio, por más que la buena fe sea considerada un principio del ordenamiento, ello no la autoriza para definir o sustentar su constitucionalización. Lo que nuestra Constitución asegura implícitamente en el Art. $19 \mathrm{~N}^{\circ} 3$ inciso $5^{\circ}$ son una serie de garantías procesales para los ciudadanos frente a la actuación jurisdiccional (derecho a defensa, imparcialidad, motivación de la sentencia, etc.), pero no asegura - porque no puede- que las partes actuarán de buena fe.

${ }^{38}$ Vid., Naranjo de la Cruz, R., Los límites de los derechos fundamentales en las relaciones entre particulares: la buena fe, op. cit., p. 404.

39 Moreno García, A., "La buena fe y derechos fundamentales en la jurisprudencia del Tribunal Constitucional”, op. cit., p. 271. 
ha constitucionalizado como un límite intrínseco al ejercicio de los derechos presenta el riesgo de abandonar el sistema constitucional y descender a otra parte del ordenamiento jurídico, en este caso, el Derecho Procesal, para extraer de ahí una determinada institución y convertirla en exigencia general para el ejercicio de un derecho fundamental. ${ }^{40}$ Sostener lo contrario implicaría sustraer a los enunciados constitucionales que consagran garantías procesales de su fuerza vinculante y entregarlos a las mayorías políticas contingentes. ${ }^{41}$ O como lo explica Naranjo de la Cruz, aceptar esta tesis constituiría un alejamiento definitivo de los parámetros constitucionales desde los que se ha de discernir la corrección de las restricciones que se imponen a las posiciones subjetivas fundamentales. ${ }^{42}$ De este modo, el derecho a defensa no podría sufrir limitaciones emparentadas con el deber de actuar conforme a la buena fe procesal, y carecería de legitimidad el deber positivo de realizar de una determinada actividad que, en pos de alcanzar la plena realización de la buena fe en el proceso, coloque en jaque el derecho a defensa.

En el derecho comparado se ha sostenido que la buena de procesal constituye un criterio o instrumento para la debida protección de los derechos fundamentales. Se trataría de un límite derivado de la necesidad de proteger a otros derechos constitucionales, especialmente para lograr plena eficacia del derecho a la tutela judicial efectiva, a la defensa, la igualdad y a un proceso con todas las garantías. ${ }^{43}$ Esta tesis es algo falaz. Cuando se afirma que la buena fe serviría para justificar la protección de otros derechos constitucionales en realidad no está operando como límite, sino que es el respectivo derecho protegido el que justifica la imposición de la limitación. La buena fe procesal es perfectamente prescindible y tiene tan solo una fuerza argumental y no el carácter de una verdadera limitación.

En consecuencia, "la necesaria supremacía que las garantías constitucionales han de tener por sobre cualesquiera otros criterios o pautas de actuación procesal impone una consecuencia obligada: la utilización de la buena fe procesal debe quedar subordinada, siempre y absolutamente, a las exigencias derivadas de las garantías constitucionales del proceso. Ninguna garantía constitucional del proceso puede ser limitada al abrigo de la buena fe procesal". ${ }^{44}$

Para finalizar esta aproximación no se puede dejar de recordar lo que ya se explicó: recurrir a la buena fe e imponer conductas a los litigantes fundadas en ella, significaría introducir un nuevo componente de inseguridad e incerteza en la definición de los derechos fundamentales, que desde hace tiempo vienen reclamando una concreción. ${ }^{45}$

${ }^{40}$ Ibid., p. 272.

${ }^{41}$ Vid., Aguiar de Luque, L., "Los límites de los derechos fundamentales”, op. cit., p. 27.

${ }^{42}$ Cfr. Naranjo de la Cruz, R., Los límites de los derechos fundamentales en las relaciones entre particulares: la buena fe, op. cit., p. 404 .

43 Vid., por todos: Picó i Junoy, J., "El debido proceso 'leal'. Reflexiones en torno al fundamento constitucional del principio de buena fe procesal”, en Justicia, Revista de Derecho Procesal, Nos. 3-2, 2004, pp. 156 y 157.

${ }^{44}$ Cachón Cárdenas, M., "La buena fe en el proceso civil”, op. cit., p. 220.

${ }^{4}$ Vid., Moreno García, A., "La buena fe y derechos fundamentales en la jurisprudencia del Tribunal Constitucional”, op. cit., p. 274. Sobre los problemas de seguridad jurídica en el sistema constitucional de 
Parece necesario dar un paso más e identificar en qué forma el derecho de defensa puede ser limitado para brindar protección a la tutela judicial efectiva o al derecho de defensa del otro litigante. ${ }^{46}$ Se produce una suerte de colisión de derechos fundamentales (derecho de defensa versus derecho a la tutela judicial efectiva, o derecho a defensa de una parte versus derecho de defensa de la otra) con la consecuente necesidad de encontrar aquel punto de equilibrio que los armonice.

Sin embargo, esta colisión de derechos o bien no existe o bien debe resolverse a favor del derecho de defensa del sujeto pasivo del deber.

Comenzaré por el primero: no existe colisión de derechos entre la tutela judicial efectiva y el derecho de defensa. Siguiendo el concepto de Aldunate se entiende que hay colisión de derechos fundamentales cuando "el efecto jurídico de la protección iusfundamental alegada por un sujeto (titular del respectivo derecho) es incompatible con el efecto jurídico perseguido por otro sujeto a partir de un alegato de protección iusfundamental". ${ }^{47}$ Ciertamente definir los extremos del contenido de la tutela judicial efectiva es un trabajo complejo y en reiteradas ocasiones se suele confundir con el derecho a un debido proceso. ${ }^{48}$ Ambos derechos toman una virtualidad de modo inescindible dado que operan simultáneamente, pero pueden ser delimitados en teoría. Por ello, es posible afirmar que la tutela judicial efectiva no presenta extremos que estén en oposición con el derecho a defensa.

En efecto, la tutela judicial efectiva tiene un contenido preciso que, en un orden cronológico, se desarrolla en que la pretensión del justiciable sea atendida por un tribunal, para luego obtener una sentencia, en principio, sobre el aspecto sustantivo de la controversia y su posterior ejecución. ${ }^{49}$ No se asegura, por tanto, un derecho a la sentencia

tutela de los derechos fundamentales en Chile, Vid., Bordalí, A., "El modelo chileno de jurisdicción constitucional de las libertades. Análisis en el marco de los valores de seguridad jurídica e igualdad constitucional”, en Revista de Derecho Universidad Austral de Chile, Vol. 18, No 1, julio, 2005, pp. 89 a 117.

46 Desde luego que esta pregunta sólo es válida en el ámbito del derecho procesal civil y no en materia penal, donde el derecho a guardar silencio emana directamente de la noción misma de la presunción de inocencia.

47 Aldunate, E., "La colisión de derechos fundamentales", en Revista Derecho y Humanidades, No 11 , 2005 , p. 69.

${ }^{48}$ Es lo que ha sucedido en el derecho español tras una serie de fallos del Tribunal Constitucional de dicho país, que ha extendido la garantía de la tutela judicial efectiva a ciertas hipótesis que se adscriben derechamente en las garantías procesales del debido proceso, entre ellas la prohibición de indefensión. Vid., Moreno Catena, V. et al., Derecho procesal civil, Tomo I, Vol. I, parte general, sexta edición, Tirant Lo Blanch, Valencia, 1992, p. 180. Ha coadyuvado a esta confusión cierta parte de la doctrina que sigue afirmando que el derecho al libre acceso a los tribunales se concreta además en que sea posible el sustanciamiento de un procedimiento con todas sus garantías. Cfr. De Bartolomé, J. C., Derechos fundamentales y libertades públicas, Tirant lo Blanch, Valencia, 2003, p. 222.

49 Vid., Cordón Moreno, F., "El derecho a obtener la tutela judicial efectiva”, en Derechos Procesales Fundamentales, CGPJ, Madrid, 2005, pp. 215 a 219. En el mismo sentido: Goig Martínez, J. M. et al., Dogmática y práctica de los derechos fundamentales, Tirant Lo Blanch, Valencia, 2006, p. 361; Picó i Junoy, J., Las garantías constitucionales del proceso, Bosch, Barcelona, 1997, pp. 40 y siguientes; Moreno Catena, V. et al., Derecho procesal civil, op. cit., pp. 179 y 180, quien define a la acción como "el derecho fundamental al proceso jurisdiccional que dé lugar a una resolución sobre el fondo del asunto cuando concurren los presupuestos procesales y los requisitos esenciales exigidos, así como al cumplimiento de lo ordenado por 
favorable como tampoco que la decisión que adopte el tribunal sea necesariamente justa. El derecho a la tutela judicial se agota, por lo tanto, en el acceso a la jurisdicción y en la dictación de una sentencia motivada en derecho, pero no se confunde con las garantías de que debe estar revestida la forma en que la jurisdicción se desarrolla. Esto último atañe más bien al debido proceso, ${ }^{50}$ a la parte dinámica del desarrollo jurisdiccional. Por consiguiente, si no hay colisión de derechos fundamentales no puede justificarse la imposición de deberes procesales positivos que coarten el derecho de defensa de una de las partes para una pretendida protección a la tutela judicial efectiva. El pleno disfrute de la tutela judicial efectiva prescinde por completo de las garantías de que puede estar revestido el desarrollo jurisdiccional.

Corresponde ahora dar un último paso: si la limitación del derecho a defensa de una de las partes puede justificarse en la protección del derecho de defensa de la otra parte. Mi respuesta es negativa. En esta situación no concurre un requisito que la teoría de los derechos fundamentales ha exigido para la legitimidad constitucional de una limitación, cual es, la necesidad. ${ }^{51}$ El principio de necesidad, según Naranjo de la Cruz, "exige que el poder público que aborda la restricción del derecho fundamental no hubiera podido elegir otra medida optativa, igualmente eficaz, pero que no requiriese la restricción del derecho fundamental o que implicase una limitación menos serena”. ${ }^{52}$ En otras palabras, el fin que se persigue con la limitación -la protección del derecho a defensa- no puede ser alcanzable a través de un medio igualmente eficaz pero menos dañoso. ${ }^{53}$

Conforme al principio de necesidad, se tiene que si el ordenamiento jurídico ofrece, para la debida protección del derecho de defensa, algún otro medio igualmente eficaz a la imposición de una limitación, debe preferirse aquel medio. O sea, si existe algún otro medio para que aquella ocultación o reticencia en la presentación de los medios de prueba, o la infracción del deber de veracidad y completitud, no lesione al derecho de defensa de la contraparte. En mi opinión, dos instituciones del Derecho Procesal podrían cumplir con idéntica eficacia y adecuación la función protectora del derecho

la resolución judicial". Vid., además, pero excluyendo la tutela cautelar y la ejecución de las resoluciones judiciales dentro del contenido del derecho de acción, Bordalí, A., "El derecho fundamental de acción: un intento de configuración en el orden constitucional chileno", en Revista de Derecho y Jurisprudencia, Tomo XCVII, N 3, 2000, p. 94.

${ }^{50}$ Como lo afirma Bordalí el derecho a un debido proceso garantiza que la respuesta judicial será fruto de una actividad que respete ciertos requisitos o principios del andar procesal que permitan legitimar de un mejor modo la justicia de la decisión judicial. Vid., Bordalí, A., "El debido proceso civil”, op. cit., p. 257.

${ }^{51}$ La doctrina en general está meridianamente conteste en afirmar que para limitar un derecho fundamental resulta indispensable que tal límite reúna ciertos requisitos. Este límite debe fundarse en el principio de proporcionalidad, que está compuesto, a su vez, por tres grandes subprincipios: la adecuación, la necesidad y la proporcionalidad en sentido estricto. Sobre el principio de proporcionalidad véase: Böckenförde, E. W., Escritos sobre Derechos Fundamentales, Editorial Nomos, Baden-Baden, 1993, p. 102; Brage, J., Los límites a los derechos fundamentales, Dykinson, Madrid, 2004, p. 415 y Naranjo de la Cruz, R., Los límites de los derechos fundamentales en las relaciones entre particulares: la buena fe, op. cit., p. 102.

52 Naranjo de la Cruz, R., Los límites de los derechos fundamentales en las relaciones entre particulares: la buena fe, op. cit., p. 104

${ }^{53}$ Vid., Brage J., Los limites a los derechos fundamentales, op. cit., p. 222. 
de defensa sin recurrir a la limitación del mismo: la atribución judicial de la carga de la prueba bajo los criterios de facilidad y disponibilidad probatoria, y la garantía de un cabal y pleno contradictorio. ${ }^{54}$

En efecto, parece claro que el proceso civil moderno debe abandonar o complementar las viejas fórmulas de distribución de la carga de la prueba (graficados en el Art. 1698 del Código Civil) introduciendo nuevos criterios de atribución judicial basados en la cercanía de las partes a las fuentes de prueba ${ }^{55}$, como la facilidad o disponibilidad probatoria. Si una de las partes no quiere colaborar con el proceso con un medio de prueba porque le es desfavorable, no resulta tolerable que el ordenamiento le imponga el deber de hacerlo; pero de igual forma, tampoco es razonable la imposición a la contraparte de la carga de acreditar un hecho cuya prueba sólo puede lograrse a través del medio de prueba cuyo dominio es de la contraparte. En este caso, el establecimiento de la carga de la prueba a quien no está en condiciones materiales de probar podría vulnerar el derecho de defensa.

Los principios de facilidad y disponibilidad probatoria ponen de manifiesto la necesidad de distribuir la carga de la prueba atendiendo no tanto a una serie de principios teóricos o a la posición que cada parte ocupa en el proceso, sino en criterios prácticos y en concreto a la proximidad real de las partes a las fuentes de prueba. ${ }^{56} \mathrm{La}$ inversión de la carga de la prueba constituye entonces un medio para evitar una limitación al derecho de defensa ${ }^{57}$ y, por ende, una forma de descartar la imposición de un deber positivo de actuación conforme a la buena fe procesal.

Parte de la doctrina ha entendido que la buena fe procesal informa los criterios de facilidad y disponibilidad en la atribución de la carga de la prueba y, en consecuencia, también se encontraría presente cada vez que recurrimos a la atribución judicial del onus probandi. ${ }^{58} \mathrm{La}$ indagación resulta, a mi juicio, errónea. La regla de actuación conforme a

\footnotetext{
${ }^{54}$ Por su importancia, la garantía del contradictorio será tratada más adelante con la profundidad y detalle que amerita.

${ }^{55}$ La separación entre fuente y medio de prueba fue realizada por Sentis Melendo. La fuente de prueba sería un concepto metajurídico, extrajurídico o ajurídico, que corresponde forzosamente a una realidad anterior y extraña al proceso. Por su parte, el medio de prueba es un concepto jurídico y absolutamente procesal. La fuente existirá con independencia de que se siga o no el proceso, aunque mientras no se llegue a él su existencia carezca de repercusiones jurídicas; el medio nacerá y se formará en el proceso. Cfr., Sentis Melendo, S., "Fuentes y medios de prueba", en La prueba. Los grandes temas del derecho probatorio, Ediciones Jurídicas Europa-América, Buenos Aires, 1979, p. 151.

${ }^{56}$ Vid., Montero Aroca, J., Derecho Jurisdiccional II, Proceso Civil, décima edición, Tirant Lo Blanch, Valencia, 2001, p. 261.

57 Siguiendo a Cortés Domínguez, la inversión de la carga de la prueba consiste en la modificación del supuesto de hecho de la norma material -modificación de la regla de juicio- más la relevatio ad oneris probandi o dispensa de prueba. De ahí que la inversión de la carga de la prueba sólo pueda darse en los estadios judiciales y convencionales. Cfr., Cortés Domínguez, V., "Algunos aspectos sobre la inversión de la carga de la prueba”, en Revista de Derecho Procesal Iberoamericana, Nos. 2-3, 1972, pp. 602 a 604.

58 Vid., Fernández López, Mercedes, La carga de la prueba en la práctica judicial civil, Editorial La Ley, Madrid, 2006, p. 148, quien señala que "el principio de buena fe procesal exige que aquel a quien le resulte más fácil la prueba de un hecho colabore activamente en la acreditación del mismo”. En el mismo sentido: Picó i Junoy, J., “Aproximación al principio de buena fe procesal en la nueva ley de enjuiciamiento civil” en
} 
la buena fe procesal no tiene como destinatario natural al órgano jurisdiccional que es, en definitiva, el que fija y determina la carga de probar conforme a la disponibilidad y facilidad probatoria. El juez no tiene el deber de distribuir cargas probatorias conforme a la buena fe procesal porque tal regla no está promovida para regular su conducta ni deberes ministeriales, sino la conducta de las partes. Por otro lado, parece más sustentable una tesis que funde estos criterios judiciales de atribución de la carga de la prueba sobre la base del respeto al derecho de defensa; gravar a una de las partes con la carga de acreditar un hecho cuya prueba resulta extremadamente dificultosa o imposible, puede generar indefensión en la medida que imposibilita al justiciable ejercer su derecho de defensa.

El Art. 14 inciso $3^{\circ}$ del Proyecto incluye una regla de distribución judicial de la carga de la prueba al disponer que "El tribunal podrá distribuir la carga de la prueba conforme a la disponibilidad y facilidad probatoria que posea cada una de las partes en el litigio."... La aplicación de este expediente permite ajustar los criterios de distribución de la carga de la prueba a situaciones compatibles con el derecho a defensa, es decir, con la cercanía y proximidad que en concreto el litigante pueda ostentar con la fuente de prueba. Permite, al mismo tiempo, prescindir de deberes que constriñan a las partes a colaborar en su detrimento con el proceso. De igual forma, el Art. 284 inciso $2^{\circ}$ del mismo proyecto contiene una disposición subsidiaria para el caso de prueba defectuosa o ausencia de prueba, donde el juez puede dar por establecido un hecho ante "la falta de acompañamiento de los medios de prueba que dispongan en su poder en la audiencia de juicio, siempre que se hubiere efectuado previamente el apercibimiento en este sentido en la audiencia preliminar". 59

\section{V. ¿Por Qué no a los Deberes POSITIVOS Fundados EN LA BUENA FE PROCESAL?}

Ahora pretendo enfrentar las razones que me llevan a sustentar la inconveniencia de que el ordenamiento jurídico permita dentro del proceso la imposición a las partes de deberes fundados en la buena fe procesal. Es decir, explicar por qué no es razonable ni sustentable una tesis que entienda que la buena fe procesal permitiría adecuar la conducta

Revista Jurídica de Catalunya, N 4, 2001, p. 958, para quien "las reglas de la buena fe inciden en la carga de la prueba, especialmente en aquellas situaciones fácticas cuya prueba es fácil para una de las partes: en estos casos la buena fe en su actuar le supone la carga de probar". De idéntica forma y similar razonamiento: González Granda, P., "Los criterios de disponibilidad y facilidad probatoria en el sistema del artículo 217 de la LEC”, en Carga de la prueba y responsabilidad civil, Tirant Lo Blanch, Valencia, 2007, p. 67.

59 A modo de crítica al precepto, no parece razonable que la prueba pueda ser equiparable a la conducta procesal de las partes, más aun cuando esta conducta procesal sólo permite ser utilizada en perjuicio de quien la efectúa y no a favor. La prueba, en cambio, por el principio de adquisición procesal admite esa doble valoración; puede ser favorable o desfavorable para quien la rinde. Por último, frente a la omisión o defecto de la prueba los ordenamientos, en general, suelen permitir al juez ordenar pruebas a través de las medidas para mejor resolver, pero no intentar sustituir esta ausencia de prueba por una valoración del comportamiento de la parte. 
de las partes a criterios de lealtad, honradez y ética. Sin perjuicio, terminaré este acápite abordando al menos un caso donde las partes o, más precisamente el demandante, tiene el deber de ser veraz y completo en la narración de sus hechos.

\section{a) El proceso como un sistema de cargas y no de deberes procesales}

No cabe duda que la veracidad de las alegaciones como emanación de la buena fe procesal sólo puede configurarse como deber procesal ${ }^{60}$ y no como carga. Sin embargo, a mi juicio, el proceso civil debiera prescindir del tal deber, y aun cuando quisiera ser configurado como carga procesal, habría graves inconvenientes.

Como se sabe, Goldschmidt ${ }^{61}$ introdujo el concepto de carga procesal para explicar su teoría de la situación jurídica: según el autor, el proceso está constituido, más que por deberes u obligaciones, por cargas, mediante cuya realización se permite evitar posibles perjuicios al propio interés, es decir, las cargas son imperativos que se determinan en razón del propio interés de la parte. ${ }^{62}$ Ahora bien, si las partes satisfacen las cargas la expectativa de obtener una sentencia favorable crece, pero no asegura el éxito de la pretensión. Frente a cada carga, el ordenamiento reconoce a las partes la titularidad de ciertos poderes jurídicos, que son ejercitados o no según los estrictos parámetros que dicta el interés personal. ${ }^{63}$ Por ende, el ejercicio de tales poderes no constituye para las partes un deber procesal, su determinación no es coartada por la amenaza de una sanción, sino que está madurada en la consideración de las consecuencias que puedan derivar de una actividad o de una inactividad en el proceso. ${ }^{64}$

Lo arriba descrito aparece dentro del Derecho Procesal en términos de evidencia. Un proceso civil se estructura mejor a través de un sistema de combinación de cargas, sin necesidad de recurrir a expedientes forzosos que obliguen a las partes a realizar, en interés de la justicia y en detrimento de su propio interés individual, actuaciones que pugnen con la tutela o defensa de dicho interés. ${ }^{65}$ Hacer que las partes asuman deberes positivos de actuación para adecuar su conducta a la buena fe procesal, o a la lealtad o eticidad, es apartar el proceso del juego de las cargas procesales y generar un campo de distorsión al imponer una actuación al litigante.

Si las partes tienen que asumir ciertos deberes que puedan colocar en riesgo sus intereses, el proceso dejaría de ser un instrumento destinado a la tutela de los derechos de las personas, para encontrar un fin en sí mismo. El proceso no se justifica por sí solo sino en cuanto se destina a la tutela de los derechos e intereses legítimos y, de igual

${ }^{60}$ Vid., Carretta, F., "Deberes procesales de las partes en el proceso civil chileno: referencia a la buena fe procesal y al deber de coherencia”, op. cit., pp. 110 a 115.

${ }^{61}$ Cfr. Goldschmidt, J., Teoría general del proceso, Editorial Labor, Barcelona, 1936, p. 100.

62 Ibid.

${ }^{63}$ Vid., Micheli, G. A., Curso de derecho procesal civil, Vol. I, Parte general, traducción de Santiago Sentis Melendo, Ediciones Jurídicas Europa-América, Buenos Aires, 1970, p. 264.

${ }^{64}$ Ibid., p. 265.

${ }^{65}$ Vid., Condorelli, E., Del abuso y la mala fe dentro del proceso, Abeledo Perrot, Buenos Aires, 1986, p. 56. 
forma, la actividad de la parte no se caracteriza por buscar la justicia de la decisión -que no tendría por qué hacerlo-, sino por obtener la protección de sus intereses y nada más que de sus intereses.

No comparto, en este punto, lo sustentado por parte de la doctrina en el sentido de que "es altamente probable que varios sujetos dirijan su conducta al solo cumplimiento de aquello que el interés social, plasmado en el ordenamiento jurídico, imponga” ${ }^{66}$ Las partes no pueden ser sujetos de deberes que pongan en tela de juicio la subsistencia del derecho subjetivo o del interés legítimo, por mucho que en el cumplimiento de tales deberes esté comprendido un declarado interés social. Cada uno de los litigantes cuenta para vencer solamente con su capacidad de hacer valer los elementos y argumentos favorables; por consiguiente, no puede pretenderse que suministre también aquellos que le son desfavorables o que pueden ayudar al adversario. Un deber en tal caso no tendría alguna posibilidad de ser observado y el único resultado sería poner en dificultad y embarazo a la parte más honesta. ${ }^{67}$

Lo más probable entonces es que pueda asumirse como válida la regla contraria a la dicha anteriormente: las partes no sentirán la necesidad de dirigir su conducta al cumplimiento de aquello que el interés social le imponga, sino a aquello que la protección de su interés particular les dicte.

Por otro lado, si lo que se pretende con este deber positivo es acercar el proceso lo más posible al valor verdad no parece ser un expediente legítimo. Parece más razonable que las partes no estén comprometidas con el deber de decir la verdad o de narrar íntegramente los hechos, sino más bien tengan cargas procesales que vencer por medio de los poderes jurídicos reconocidos por el ordenamiento, con el objeto de probar que sus afirmaciones eran verdaderas. ${ }^{68}$ Pretender construir un ordenamiento que intente persuadir a las partes a decir la verdad o a ejecutar unos determinados actos para alcanzar la buena fe procesal, está desencajado de la realidad. Serra Domínguez ya lo decía, con cierta exageración, que un deber de veracidad estrictamente actuado podía incluso hacer sobrar al proceso, que quedaría reducido a alegaciones y sentencia ante la innecesidad de la prueba. Por ello, fundaba la incompatibilidad del deber de veracidad con la naturaleza misma del proceso. ${ }^{69}$

${ }^{66}$ Carretta, F., "Deberes procesales de las partes en el proceso civil chileno: referencia a la buena fe procesal y al deber de coherencia”, op. cit., pp. 112.

${ }^{67}$ Vid., Liebman, E. T., Manuale di diritto processuale civile, Principi, Giuffrè Editore, Milán, 1992, p. 114. Como lo afirma Serra Domínguez, "de acogerse el principio sería peor (sic) condición la parte que cumpliera el deber que aquella otra que lo infringiera. Únicamente en un mundo ideal en que todos los ciudadanos declaran la verdad, aun cuando ésta pudiera suponerles un grave perjuicio, podría admitirse un deber de veracidad”. Serra, M. "Liberalización y socialización del proceso civil", en Revista de Derecho Procesal Iberoamericana, $\mathrm{N}^{\text {os. }} 2-3,1972$, p. 543.

${ }^{68}$ Vid., Condorelli, E., Del abuso y la mala fe dentro del proceso, op. cit., p. 265.

${ }^{69}$ Cfr. Serra, M., "Liberalización y socialización del proceso civil", op. cit., p. 543. De igual forma, un proceso diseñado sobre deberes procesales, en vez de cargas procesales, coloca en el mismo plano a los terceros extraños al pleito que tienen que sacrificar su propio interés para servir a los fines de la justicia, y a las partes, que serían concebidas no como sujetos que concurren a un tribunal para la tutela de sus derechos 
Por otro lado, el deber de veracidad y colaboración resultan imposibles de ser encuadrados dentro de la teoría de la carga procesal. ${ }^{70}$ Como se dijo, una de las cuestiones principales de la teoría de la carga procesal es que confiere al individuo ciertos poderes jurídicos para vencerlas, de manera que su satisfacción o cumplimiento ponía a la parte en una situación de expectativa de una sentencia favorable. La pregunta razonable será entonces: ¿en qué sentido se reafirma la expectativa de una sentencia favorable cumpliendo con la carga procesal de decir la verdad de forma íntegra o colaborando con el proceso? El establecimiento de la carga procesal de decir la verdad y de ser completo en la narración de los hechos, sólo funciona como tal -es decir, como carga- si al mismo tiempo se le da a la parte el derecho a ser creído. ${ }^{71}$ Solamente en un proceso que vincule la declaración de la parte a una situación de expectativa favorable para quien hace la declaración es admisible hablar de cargas. Pero, por lo general, sucede todo lo contrario, o sea, cuando la parte satisface la carga procesal (diciendo la verdad y en forma completa, o colaborando con el proceso), no genera ninguna situación de expectativa favorable. Su actuación de buena fe puede llevarlo incluso al fracaso de su pretensión, poniendo en riesgo el derecho o interés cuya tutela se busca. Como afirma Carnelutti, toda carga procesal es un estímulo para las partes ${ }^{72}$, por lo que en esta hipótesis falta aquel estímulo positivo que incentiva su satisfacción.

Como último comentario precisaré que no pretendo descartar la existencia de deberes dentro del proceso, de hecho los hay y no en pocas ocasiones (será el ejemplo más palmario el deber de comparecer que tienen las partes). Tan solo acotar que ellos no pueden entrar en tensión con los derechos fundamentales de corte procesal ni con el principio dispositivo. Creo que una teoría general que enfrente la posibilidad de derivar deberes de la buena fe procesal no puede dejar de conectarse con las garantías procesales.

\section{b) El contradictorio y el deber de veracidad y completitud}

La correcta y completa verificación de un contradictorio entre las partes será el mecanismo más espontáneo para alcanzar la plenitud y verdad del entramado fáctico. La noción misma de proceso, como forma de desarrollo de la actividad jurisdiccional, lleva implícita la idea de un contradictorio en igualdad entre los litigantes. O sea, no es necesario justificar la necesidad de incluir la contradicción, desde que la propia Constitución exige que el desarrollo jurisdiccional se actúe por medio de un proceso. Por

e intereses legítimos, sino que como instrumentos al servicio del interés público, sirviendo, si dicho interés lo exige, a emplearse para la propia derrota.

${ }^{70}$ En contra Zeiss para quien el deber de veracidad no puede entenderse como deber procesal sino únicamente como carga de veracidad. Cfr. Zeiss, W., El dolo procesal. Aporte a la precisión teórica de una probibición del dolo en el proceso de cognición civilístico, Ediciones Jurídicas Europa-América, traducción de Tomás A. Banzhaf, Buenos Aires, 1979, p. 25.

${ }^{71}$ Vid., Scarselli, G., "Lealtà e probità degli atti processuali”, op. cit., p. 107.

72 Cfr., Carnelutti, F., “Líneas generales de la reforma del proceso civil de cognición”, en Estudios de Derecho Procesal, Vol. I, traducción de Santiago Sentis Melendo, Ediciones Jurídicas Europa-América, Buenos Aires, 1952, p. 92. 
ende, trataré de definir los contornos de la contradicción y de explicitar cómo a través de él se puede llegar a prescindir de la imposición de estos deberes procesales.

En primer término, por contradictorio debe entenderse a aquel conjunto de reglas que, desde la constitución de la relación procesal hasta la decisión del juicio, disciplinan el diálogo abierto entre los sujetos en litis, en vista de un objetivo común: la elaboración del contenido de la sentencia final. ${ }^{73}$ Este mecanismo permite a las partes hacer cumplir su función básica en el proceso, esto es, el legítimo interés a influir y contribuir a la formación de la decisión del juez con informaciones, demostraciones, críticas y polémicas. $^{74}$

Lo que se quiere por medio del contradictorio es que las partes desde sus parciales puntos de vista puedan ilustrar al juez acerca del contenido de su pretensión y resistencia, ayudando a formar la convicción sobre la verdad o falsedad de los hechos invocados. Si las actuaciones de las partes están conducidas por el cuidado de sus propios intereses, no cabe duda que agregarán los datos omitidos por la contraparte en su narración, negarán o rectificarán aquellos hechos que entiendan que no guardan relación con la verdad. En esto consiste precisamente el carácter dialéctico del proceso. El proceso no es solamente un conjunto sucesivo de actos establecido en la ley, sino una concatenación lógica que sintoniza a cada acto de la parte con aquel que lo precede y lo sigue; el nexo psicológico del acto que una parte efectúa, en su momento justo, constituye una premisa y un estímulo para el acto que la contraparte podrá efectuar en un instante posterior. ${ }^{75}$ Cada afirmación falaz e incompleta será un estímulo para que la contraparte agregue los hechos omitidos y rectifique los falseados. Al igual que los movimientos de un juego, el proceso da lugar a una serie de actos que se entrecruzan: demandas y respuestas, réplicas y contrarréplicas, acciones que dan lugar a reacciones, etc., todas ellas destinadas a controvertir los efectos del acto que lo precede. ${ }^{76}$

La imposición de un deber procesal de narrar los hechos en forma verídica y completa a una o ambas partes genera una distorsión en la dialéctica procesal, ya que el diálogo deja de ser libre y espontáneo para convertirse en una imposición externa. La posibilidad de contradecir no es más que aquello, una simple posibilidad, y no un deber, por ello en la noción de contradictorio está latente la idea de libertad. No resulta compatible con este modelo lógico-formal de contradicción la asignación a los litigantes de determinados deberes positivos de veracidad y completitud para la adecuación de su conducta a la buena fe procesal. El principio de contradictorio se agota en la mera posibilidad de actuar, es una potestad para el ciudadano de concurrir a defender sus intereses y no una conminación externa a decir o hacer algo, forzado por la consecución de la "justicia” o la ética procesal.

${ }^{73}$ Vid., Comoglio, L. P., "El Il comma dell'art. 24. Il diritto di difesa nel processo civile”, en Commentario della Costituzione. Rapporti Civile, a cura de Giuseppe Branca, Nicola Zanichelli Editore, Bolonia, 1988, p. 59.

\footnotetext{
${ }^{74}$ Vid., Satta, S., Diritto Processuale Civile, Cedam, Padova, 1948, p. 189.

75 Vid., Calamandrei, P., "Il processo come gioco" op. cit., p. 27.

${ }^{76}$ Ibid.
} 
No se trata, por cierto, de admitir cualquier tipo de acto o artimaña para ganar en la lucha: el proceso está sujeto a reglas que los litigantes deben observar, pero estas reglas no pueden significar afectar la esencia del proceso, es decir, dificultar o poner en riesgo la efectividad de un verdadero contradictorio.

A mi juicio, el proceso civil se debe orientar a maximizar el libre contraste de las tesis procesales a objeto de que su resultado permita al juez extraer los mejores datos, argumentos y razonamientos posibles. En consecuencia, los litigantes deben tener la facultad y oportunidad para actuar en la contradicción, asegurar uno o varios momentos para rebatir los dichos de su adversario, agregar hechos contrapuestos o que pueden anular la eficacia de los primeros; en síntesis, generar espacios de libertad para orientar al juez a una sentencia favorable. No serían tolerables en un proceso mermas a la libertad del justiciable para la concreción de ideales tan abstractos como la "justicia”, como si ésta fuese una cuestión diferente a la tutela y respeto de los derechos e intereses objeto del juicio.

Pero el contradictorio no sólo sirve para permitir la lucha de fuerzas de los litigantes, sino también es un instrumento operativo del juez y uno de los momentos fundamentales del juicio que sirve a los fines de buscar y encontrar una verdad probable. ${ }^{77}$ En otras palabras, el juez, junto con hacer observar el contradictorio, debe observarlo él mismo, provocando de oficio el debate preventivo entre las partes sobre todas las cuestiones de hecho y de derecho que sean determinantes para la resolución de la controversia. ${ }^{78}$ La tarea del juez es fomentar que en cada etapa del proceso y respecto a todas las materias relevantes se promueva un contradictorio entre las partes, y no asumir una función ajena a la juzgadora y, eventualmente, la probatoria. Asignar esta función al órgano jurisdiccional parece mucho más realista y respetuosa a la imparcialidad que aquella que pretende convertirlo en un sujeto que auxilie a la parte más débil económicamente o la peor defendida, o bien se le asigne la misión de lograr la plenitud del entramado fáctico, haciendo cumplir a las partes el deber de verdad. Será entonces la dialéctica procesal, por medio de un contradictorio, el medio más adecuado para satisfacer los fines públicos presentes en cada proceso.

En consecuencia, la real discusión debería acomodarse en cómo configurar un contradictorio que coloque a las partes en la genuina posibilidad de conocer con anticipación la tesis contraria, a fin de concurrir a la formación del convencimiento del juez. ${ }^{79}$ Esto implica reducir los ámbitos procesales donde es lícito a las partes sorprender con hechos nuevos y conjurar la posibilidad de rebatir, discutir y proponer prueba para restar la eficacia de los hechos nuevos agregados durante la litis.

${ }^{77}$ Vid., Picardi, N., "Il principio del contraddittorio", en Rivista di Diritto Processuale, año LII, No 3 , 1998, p. 680.

${ }^{78}$ Vid., Trocker, N., "Il nuovo articolo 111 della costituzione e il 'giusto procceso' in materia civile: profili generali", en Rivista Trimestrale di Diritto e Procedura Civile, año LV, 2002, p. 394, y Bove, M., "Art. 111 Cost. E 'Giusto processo civile’”, en Rivista di Diritto Processuale Civile, año LVII ( $2^{\mathrm{a}}$ serie), $\mathrm{N}^{\circ} 2$, abriljunio 2002, p. 500 .

${ }^{79}$ Vid., Comoglio, L. P. "El Il comma dell'art. 24. Il diritto di difesa nel processo civile”, op. cit., p. 58. 
Alguien podría decir que la visión del contradictorio expuesta corresponde a una versión apegada a lo liberal-individualista, que se contrapone con la realidad, y que hoy en día está sujeta a inevitables críticas derivadas de una inexistente igualdad sustancial de las partes, única forma de entender que el libre encuentro de las partes lleve a una solución justa de la controversia. ${ }^{80}$ La crítica es correcta. Pero no creo que exista otro mecanismo dentro del proceso capaz de fomentar un libre juego de las afirmaciones de hecho. De esta crítica, además, no se colige que deba fomentarse la actuación de la buena fe procesal como un método correctivo de la desigualdad sustancial. Asumir tal desequilibrio es un presupuesto necesario para idear un contradictorio realmente eficaz que no puede, sin embargo, ser a costa de sacrificar la imparcialidad del juzgador. Por ende, prefiero un proceso que busque la igualdad procesal en otros mecanismos como el patrocinio gratuito e incluso en la distribución de la carga de la prueba, pero que jamás asuma que los deberes que emanan de la buena fe o la función auxiliar del juez son recursos válidos para lograr tal finalidad.

Parte de la doctrina ha entendido que el proceso no es una lucha o guerra y, por tanto, no todo es lícito o válido. ${ }^{81}$ Literalmente nunca lo ha sido. Es verdad que dentro del proceso no todo está permitido. Creo que nadie sustentaría la existencia de un proceso sin reglas, que, al fin de cuentas, sería un proceso sin garantías. Pero el respeto por las reglas procesales equivale, en este parangón, al respeto de las reglas del fair play, y éstas no conminan a los jugadores a descubrir la estrategia de su juego, ni a "mostrar sus cartas". ${ }^{82}$ Las reglas propiamente jurídicas constituyen una especie de marco dentro del cual puede espaciarse el poder dispositivo de las partes, y sólo en la observancia de estas reglas marginales la actividad de la parte es jurídicamente vinculante y esencialmente libre. ${ }^{83}$ Además, aun cuando pueda descartarse que el proceso se trate de un lugar de lucha o guerra, tampoco es un lugar sacrosanto de colaboración, ayuda y cooperación recíproca entre los litigantes.

\section{c) Inocuidad de la mentira e irrelevancia práctica del deber de veracidad y completitud}

Cuando opino que la mentira es inocua hago referencia, esencialmente, a la afirmación o alegación fáctica mendaz, lo que no significa que sea éticamente correcta. En efecto, la inocuidad de la afirmación mentirosa proviene de su carácter salvable, ya que está sujeta a un control de confirmación por medio de la prueba -sea de parte o del juez-, con lo que será posible revelar cuál afirmación es falsa y cuál es verdadera. ${ }^{84}$ Si bien la mentira

${ }^{80}$ Vid., Proto Pisani, A., Lezioni di diritto processuale civile, Jovene Editore, tercera edición, Nápoles, 1999, p. 218.

${ }^{81}$ Vid., Picó i Junoy, J., El principio de la buena fe procesal, op. cit., p. 135, y Grossmann, K., "El deber de veracidad de las partes litigantes en los juicios civiles. Exposición de Derecho Comparado”, op. cit., p. 20.

${ }^{82}$ Vid., Calogero, G., "Probità, lealtà, veracità nel processo civile”, op. cit., pp. 133 a 134.

${ }^{83}$ Vid., Calamandrei, P., "Il processo come gioco", op. cit., p. 30.

${ }^{84}$ En contra Grossmann para quien la circunstancia de que las probables objeciones no podrán comprobarse no autoriza para alterar el fundamento de la demanda, como tampoco existe el derecho del demandado 
pretende influir sobre el resultado del pleito, su sola afirmación no puede ser considerada suficiente para llevar a error al juzgador. Se requiere de algo más que la simple afirmación mendaz, es indispensable que el error en el juicio del tribunal provenga de maquinaciones fraudulentas de la parte, de la aportación de medios de prueba falsos capaces de generar en el juez una falsa representación de los hechos, en síntesis, de todo tipo de elemento capaz que inducir o provocar un engaño en el órgano jurisdiccional. ${ }^{85}$

Los relatos de las partes raramente coincidirán y serán por lo general antagónicos. Las partes, al estar en posiciones contrapuestas, ven las cosas desde su particular punto de vista. ${ }^{86}$ "En los procesos civiles reales, en esos que se realizan en la práctica, un abogado narra una historia y la narra de su 'verdad', desde la perspectiva que favorece a los intereses de su cliente, y el otro abogado narra la misma historia y lo hace también desde su 'verdad', destacando lo que favorece a los intereses de su cliente". ${ }^{87}$ En esta hipótesis -que por cierto será la más frecuente- decir o no la verdad de forma íntegra será completamente irrelevante, en la medida que cada parte se cree dueña de una verdad que intenta justificar de su parcial punto de vista. Si las partes no comparten sus narraciones por ser contadas desde puntos contrapuestas, sobre ángulos distintos y en cierta forma adaptada al cuadro que propone su estrategia, entonces será la prueba la que revele la falsedad o verdad de los hechos. ${ }^{88}$

El control de la veracidad y completitud de las alegaciones de las partes es efectuado por el juez sólo en la sentencia definitiva, una vez que se ha rendido toda la prueba y que las partes han intentado acreditar los hechos alegados por ellas. Por lo que, de igual forma, se debe efectuar una actividad probatoria, y si una de las partes se arriesga a mentir, esa mentira no afectará al desarrollo del proceso si no es confirmada por la prueba.

\section{d) Deber de veracidad y completitud en las alegaciones y el principio dispositivo}

Buena parte de la doctrina ha insistido en la plena compatibilidad entre el principio dispositivo y el deber de veracidad. Cappelletti y Micheli caminan por idénticos derroteros: limitan la aplicación del principio dispositivo a la libertad de los litigantes para alegar o no un determinado hecho, pero una vez que han decidido alegarlo, deben hacerlo verazmente conforme a la buena fe y, por ende, deben ser verídicos. ${ }^{89}$ Para Grossmann,

para negar los hechos verídicos de la demanda si no dispusiere de pruebas para sus justas objeciones. Vid., Grossmann, K., "El deber de veracidad de las partes litigantes en los juicios civiles. Exposición de Derecho Comparado”, op. cit., p. 20.

${ }^{85}$ Vid., Gisbert, M., "La estafa procesal en el proceso civil: su apreciación por los tribunales", en Revista de Derecho Procesal, Nos. 1-3, 2004, p. 318.

${ }^{86}$ Vid., Cipriani, F., "El abogado y la verdad”, en Revista del Poder Judicial, Nº 72, 2003, p. 176.

${ }^{87}$ Montero Aroca, J., "Ideología y proceso civil. Su reflejo en la buena fe procesal”, op. cit., p. 311.

${ }^{88}$ Hay otros tantos casos, que también se presentan en la realidad procesal, que impiden abogar por un deber de veracidad y completitud. Se trata de situaciones donde las partes carecen del completo dominio de los hechos de forma que no están en condiciones efectivas de afirmar o negar la veracidad de una afirmación.

${ }^{89}$ Cfr. Cappelletti, M., El testimonio de la parte en el sistema de oralidad. Contribución a la teoría de la utilización probatoria del saber de las partes en el proceso civil, op. cit., pp. 373 y 374, y Micheli, G. A., La carga de la prueba, op. cit., p. 151. 
si bien el principio dispositivo se propone asegurar la máxima libertad de las partes para la formulación de su demanda y excepción, se sobreentiende que esta libertad ha de contenerse por los límites exigidos por la finalidad del juicio. De esta manera, si bien las partes tienen el derecho a elegir el material de hecho que debe ser objeto del examen del juicio, una vez efectuada la elección deben presentarlo en forma verídica. ${ }^{90}$

La tesis arriba expuesta sólo demuestra la compatibilidad del principio dispositivo con el deber de veracidad. Como se había dicho, tanto Cappelletti como Micheli lo fundamentan en la buena fe procesal, mientras Grossmann entiende que siendo la finalidad del proceso llegar al descubrimiento de la verdad puede imponerse a las partes el deber de formular sus alegaciones verazmente. ${ }^{91}$ Otros autores como Silva Melero entienden que decir la verdad es necesario para alcanzar el respeto al valor justicia. ${ }^{92}$

Por otra parte, se conecta con el principio dispositivo el deber de ser íntegro en la narración de los hechos. Según la doctrina este deber no puede exigirse en un proceso civil inspirado por el principio dispositivo, en virtud del cual las partes son absolutamente libres para disponer de sus intereses privados y reclamarlos o no judicialmente. ${ }^{93}$ En consecuencia, las partes pueden omitir datos que consideren perjudiciales para la tutela de sus intereses; así como también es correcto que eviten la aportación inicial de los documentos que estimen inoportunos para su debida defensa. ${ }^{94}$

En este sentido, sería contrario al principio dispositivo el Art. 262 del Proyecto en la medida que establece el deber -o carga si se quiere- del demandado de "pronunciarse categóricamente sobre la veracidad de los hechos alegados en la demanda”, siendo considerado su silencio o sus respuestas evasivas o ambiguas como admisión de los hechos. ${ }^{95}$ Si el principio dispositivo se conecta con la libertad de las partes de alegar o no un hecho, es decir, si ellas tienen la libertad de callar si su interés o derecho subjetivo así lo requiere, no resulta compatible un deber que imponga al demandado -y solo a él- manifestar su

${ }^{90}$ Cfr. Grossmann, K., "El deber de veracidad de las partes litigantes en los juicios civiles. Exposición de Derecho Comparado”, op. cit., p. 19.

${ }^{91}$ Ibíd., p. 16. Creo compartir con la autora la idea de un proceso orientado hacia la verdad. Pero no parece que sea esta la relación (alegación-verdad) donde resulta adecuado alcanzar la verdad, sino más bien en la relación prueba-verdad. En efecto, la relación entre prueba y verdad tiene un sustento teleológico desde que no confiere al valor verdad ningún papel definitorio de la prueba, sino que la considera el objetivo final de la actividad probatoria. La finalidad principal de la actividad probatoria es alcanzar el conocimiento de la verdad de los hechos, finalidad que no puede sostenerse que sea siempre compartida por los sujetos que intervienen en el proceso. Así, la prueba debe considerarse el instrumento con que se vale el juez para conocer aquella realidad extraprocesal necesaria para la adjudicación del caso. Cfr. Ferrer, J., Prueba y verdad en el Derecho, Editorial Marcial Pons, Madrid, 2002, p. 61.

${ }^{92}$ Cfr., Silva Melero, V., "El llamado deber de decir verdad en el proceso civil”, en Revista General de Legislación y Jurisprudencia, tomo 188, año 85, Madrid, 1936, p. 723 (718 a 734).

${ }^{93}$ Cfr. Cappelletti, M., El testimonio de la parte en el sistema de oralidad. Contribución a la teoría de la utilización probatoria del saber de las partes en el proceso civil, op. cit., pp. 372 y 373.

${ }^{94}$ Cfr. Picó i Junoy, J., El principio de la buena fe procesal, op. cit., p. 140 y Gisbert, M., "La estafa procesal en el proceso civil: su apreciación por los tribunales", op. cit., p. 317.

95 Para una fundada crítica a la construcción de verdades procesales a través del acuerdo de los litigantes, puede verse: Taruffo, M., “¿Verdad negociada?”, en Revista de Derecho Universidad Austral de Chile, Vol. XXI, N 1, 2008, pp. 129 a 151. 
conformidad o no a la verdad de un elemento fáctico señalado en la demanda. El respeto al principio dispositivo debe permitir a la parte abstenerse de hablar cuando resulte un peligro su propio interés. Un sistema que no autoriza a la parte a guardar silencio se incardina hacia un norte completamente incompatible con el principio dispositivo: implica en cierta forma la total absorción del interés individual en el interés público de la justicia. ${ }^{96}$

Lo dicho no significa que la verdad no sea un fin deseable del proceso. Me parece, en cambio, que será el mismo principio dispositivo el que fomentará un deber de veracidad. No se trata, como lo explica Montero ${ }^{97}$, de contrastar un deber de veracidad con un derecho a mentir, como lo suele entender Cipriani. ${ }^{98}$ Sustentar la inexistencia de un deber de veracidad no significa afirmar correlativamente un derecho a mentir. La mentira es una pésima estrategia procesal y la construcción de historias basadas en falsedades difícilmente llevarán al triunfo de la parte mendaz. Un trabajo de persuasión, que corresponde al que buscan los litigantes en juicio, no se condice con la elaboración de mentiras o historietas. Si los ciudadanos quieren proteger eficazmente sus derechos e intereses legítimos, lo más seguro es que opten por decir la verdad cuando ella no les acarree perjuicio alguno y callen -como les es legítimo hacerlo- cuando exista un conflicto entre la declaración del hecho y su interés.

Apelar al principio dispositivo como mecanismo natural de la veracidad de las declaraciones de hecho parece ser el elemento más razonable y plausible en un proceso que busque, precisamente, proteger los derechos e intereses de las partes.

\section{e) La garantía del derecho de defensa: la probibición de la indefensión}

El último de los argumentos que me parece válido para cuestionar un pretendido deber de colaboración o veracidad fundado en la buena fe es su incompatibilidad con el derecho a defensa. Corresponde definir en qué medida la imposición de estos deberes implica lesionar dicha garantía constitucional. Y mi premisa es que la imposición de estos deberes afecta la defensa jurídica.

En efecto, la doctrina ha dicho que la indefensión consiste "en no sufrir en el seno del proceso una privación o limitación de las posibilidades esenciales del derecho de defensa -alegación y/o prueba- (...) siempre que tal privación o limitación de la defensa acarree un perjuicio efectivo y definitivo a los derechos e intereses sustantivos del justiciable". 99

Parece evidente que cae en una hipótesis de indefensión el litigante que ve coartada la libertad en sus alegaciones de hecho o en sus actos probatorios, ya sea debiendo declarar

96 Vid., Condorelli, E., Del abuso y la mala fe dentro del proceso, op. cit., p. 57.

97 Cfr., Montero Aroca, J., "Ideología y proceso civil. Su reflejo en la buena fe procesal”, op. cit., pp. 310 y 311 .

${ }^{98}$ Cfr., Cipriani, F., "El abogado y la verdad”, op. cit., p. 177.

${ }^{99}$ Díez-Picazo Jiménez, I. et al., El derecho a la tutela judicial y el recurso de amparo. Una reflexión sobre la jurisprudencia constitucional, Civitas, Madrid, 1995, p. 100. 
la verdad de modo íntegro o teniendo el deber de colaborar con los medios de prueba de que dispone. Hay una limitación ilegítima e injustificada en sus posibilidades de defensa. Con todo, no se trata de sostener que los litigantes tengan derecho a ocultar las pruebas o dificultar su práctica, o que puedan mentir a destajo, sino simplemente afirmar que no tienen el deber de suministrar la prueba que le corresponde asumir a la contraparte, como tampoco afirmar aquellos hechos que suponen una merma en su derecho e interés legítimo y que por el juego procesal deban ser afirmados por la otra parte. ${ }^{100}$

En este sentido, el proceso debería orientarse a repeler toda conducta cuya observancia redunde en un detrimento al interés o a la defensa, como sería el deber de ser veraz y completo, y el deber de colaboración. Tales exigencias resultarían manifiestamente inconciliables con la garantía de la defensa en juicio y eventualmente con el principio dispositivo. ${ }^{101}$

\section{f) ¿Cuándo existe el deber de decir la verdad y de ser completo en la exposición de los bechos?}

Al menos existe un caso donde es exigible un deber de veracidad en las afirmaciones de hecho. Se trata de situaciones donde el ordenamiento jurídico, de modo excepcional, permite pronunciamientos inaudita altera parte, es decir, sin escuchar previamente las alegaciones de la otra parte. ${ }^{102}$ Es el caso, por ejemplo, de la dictación de las medidas cautelares, sea conservativas o innovativas, donde el ordenamiento permite obtener la conservación del patrimonio del demandado o una tutela provisional con la sola narración de los hechos que disponga el demandante y sin escuchar la versión del demandado.

Sin embargo, en este caso no sólo es la buena fe procesal la que justifica tal deber de veracidad y completitud, sino también -incluso en mayor medida- la ausencia de un contradictorio previo y el correlativo "derecho a ser creído" que tiene el demandante. Si el actor quiere obtener del juez una resolución favorable a sus intereses sin oír al principal afectado por la misma, resulta necesario que se le imponga el deber de ser veraz y completo en la narración de los hechos. Con este deber no se constriñe al actor a ejecutar un acto que pugne con sus intereses; por el contrario, la parte utiliza un instituto al cual no tiene el deber de recurrir, pero si quiere obtener dicha protección que excepcionalmente prescinde de la versión de la contraparte puede exigirse un comportamiento sincero y veraz. A diferencia de un deber general de veracidad y completitud aquí la parte no pone en riesgo su derecho o interés legítimo diciendo la verdad, sino que obtiene, siendo veraz y completo, un beneficio directo hacia la tutela del mismo.

${ }^{100}$ Vid., Calamandrei, P., Derecho Procesal Civil, tomo III, traducción de Santiago Sentis Melendo, Ejea, Buenos Aires, 1986, p. 259; García Solá, M., "De la necesidad de compatibilizar en el proceso el principio del 'abuso del derecho' con la garantía de defensa en juicio”, en Abuso Procesal, Peyrano J., director, Editorial Rubinzal-Culzoni, Buenos Aires, 2001, p. 34.

101 Vid., Palacios, L., Manual de Derecho Procesal Civil, LexisNexis, decimoséptima edición, Buenos Aires, 2003, p. 232 y Calamandrei, P., Derecho Procesal Civil, op. cit., p. 286.

102 Cfr. Scarselli, G., "Lealtà e probità degli atti processuali”, op. cit., p. 107. 


\section{EL VERDADERO LUGAR DE LA BUENA FE PROCESAL}

Como cuestión fundamental me parece que es necesario reemplazar o sustituir dicho concepto por la prohibición de actuar de mala fe ${ }^{103}$ De lo que se trata es de exigir a las partes ciertos comportamientos negativos, de mera abstención o prohibición, fundados en la proscripción de la mala fe procesal. Por ende, la simple omisión o actitud pasiva de no hacer algo para adecuar su conducta a la buena fe procesal no puede ser encuadrada como un acto de mala fe y ser objeto de sanciones.

En definitiva, una cuestión es afirmar una repulsa general a toda actuación contraria a la buena fe y otra muy distinta es afirmar al mismo tiempo la imposición de deberes positivos destinados a encauzar la libertad de los litigantes, constriñéndola a ejecutar actos que pueden perjudicarlos.

Por ello, a mi juicio, hay que ser muy cuidadosos en afirmar que la buena fe procesal constituye una fuente ilimitada de deberes procesales: por cierto lo será de aquellos que impidan el triunfo de la mala fe a través de actos dilatorios, temerarios, infundados o maliciosos, pero en ningún caso podrá poner a las partes en la situación de hacer algo en pos de la justicia y en contra de sus derechos e intereses legítimos. En simples palabras, no se trata de negar la función normativa de la buena fe procesal sino de acotarla lo máximo posible para no colisionar con los derechos fundamentales. ${ }^{104}$ En lo específico, creo que la fórmula propuesta se reduce en reivindicar no un comportamiento conforme a la buena fe procesal, sino un comportamiento sin mala fe procesal.

Teniendo presente las ideas expuestas, y sin pretensiones de ser exhaustivo, a continuación señalaré algunos parámetros que deben orientar la interpretación del Art. 8 del Proyecto, en orden a determinar el verdadero sitial de la buena fe procesal en el proceso civil:

\section{a) No caben los deberes positivos de buena fe procesal}

Por de pronto, y como premisa general, un ejercicio de hermenéutica no puede llevar a sustraer del texto legal deberes positivos de actuación. Los litigantes, ya sea la parte personalmente o sus defensores, no pueden ser obligados a ejecutar actos para adecuar su conducta a la buena fe procesal. Por lo tanto, no son contrarias a la buena fe procesal las conductas omisivas. ${ }^{105} \mathrm{Si}$ una de las partes se limita a no hacer algo no puede ser sancionado por su omisión.

\footnotetext{
103 Vid., Montero Aroca, J. "Ideología y proceso civil. Su reflejo en la buena fe procesal”, op. cit., p. 317.
}

${ }^{104}$ Particularmente lúcida es una sentencia de la Corte de Apelaciones de Santiago de 9 de noviembre de 1992, que curiosamente casi por instinto tiene el mérito de hacer referencia a los dos extremos tratados en este trabajo: primero que se debe sancionar "cualquier exceso en el uso de expedientes dilatorios o pretensiones infundadas". Y luego que "ello no implica coartar el derecho de defensa que le asiste a cada litigante, pudiendo ejercitar todos los recursos o mecanismos procesales para asegurar su pretensión, aunque dicho ejercicio cause daño a otro, lo que normalmente va a ocurrir en un litigio". C. Apelaciones de Santiago, 9 de noviembre de 1992, Legal Publishing No 20074. La cursiva es mía.

${ }^{105}$ Vid., Scarselli, G., "Lealtà e probità degli atti processuali", op. cit., p. 97, quien habla de conducta "involuntaria" como equivalente a la conducta omisiva. La conducta desleal, según el autor, requiere de un acto voluntario: por el contrario, la conducta omisiva, cual único acto procesal involuntario, no puede constituir un comportamiento desleal. 


\section{b) Se deben sancionar los actos ejecutados de mala fe}

En consecuencia, la norma en cuestión debe estar destinada a la sanción de los actos procesales ejecutados de mala fe. Al mismo tiempo, "se entiende que estamos ante una actuación contraria a la buena fe siempre que se sobrepasan los límites normales del ejercicio de un derecho con daño a un tercero". ${ }^{106}$ Caben dentro de esta categoría los actos ejecutados con abuso de derecho, los actos con fraude a la ley y los actos con fraude procesal, ${ }^{107}$ este último expresamente consagrado en el Art. 8 inciso $2^{\circ}$ del Proyecto.

Así deberían sancionarse como contrarios a la buena fe procesal: los incidentes manifiestamente dilatorios; la utilización de medidas cautelares de modo irrazonable, desproporcionadas o con un manifiesto ánimo amedrentador; la obtención de una medida cautelar inaudita altera parts habiendo falseado los hechos u omitido alguna circunstancia relevante que hayan inducido al juez a representarse un falso peligro en la demora o apariencia del buen derecho; el impedir u obstaculizar la práctica de un medio de prueba; presentar a sabiendas medios de prueba falsos; efectuar recusaciones manifiestamente infundadas; formular una demanda temeraria manifiestamente improponible por carecer de todo fundamento jurídico y fáctico plausible, etc. Todos estos actos se caracterizan por tratarse de actuaciones ejecutadas de mala fe.

Hay que tener mucho cuidado y prudencia cuando se califica uno de estos actos como contrario a la buena fe procesal. Por lo general, los actos que son objeto de tal enjuiciamiento constituyen actos ejecutados en el ejercicio de una facultad procesal, por consiguiente, una interpretación demasiado extensiva puede llegar a afectar la esencia del derecho a defensa. Si uno de los litigantes interpone y pierde un incidente procesal con la convicción de estar en la razón jurídica y fáctica, no por eso se ejecuta un acto de mala fe. Serán las circunstancias objetivas del caso las que determinarán dicha calificación. ${ }^{108} 109$

106 González Granda, P., La nueva ley de enjuiciamiento civil, Tomo I, Cortés Domínguez y Moreno Catena (coord.), editorial Tecnos, Madrid, 2000, p. 244.

${ }^{107}$ Hay abuso de derecho cuando "se lleva a cabo una actuación procesal que, si bien aparece normalmente amparada en un derecho (o facultad) previsto en una determinada norma, va dirigida, en realidad, a conseguir un resultado opuesto al que persigue dicha norma al otorgar el derecho o facultad de que se trate". Asimismo, hay fraude de ley procesal o fraude procesal cuando "se lleva a efecto una actuación procesal (fraude de ley procesal) o un entero proceso (fraude procesal) bajo el amparo formal de una determinada norma de cobertura (fraude de ley procesal) o del conjunto de normas reguladoras del proceso en cuestión (fraude procesal), pero con la finalidad de lograr un resultado que no sólo es distinto del perseguido por esa norma o conjunto normativo sino que también resulta contrario al ordenamiento jurídico”. Cachón Cárdenas, Manuel, "La buena fe en el proceso civil”, op. cit., p. 247. En el similar sentido: Picó i Junoy, J., "El debido proceso 'leal'. Reflexiones en torno al fundamento constitucional del principio de buena fe procesal”, op. cit., pp. 162 a 166, quien destaca la dificultad en la delimitación entre estos conceptos y la buena fe procesal.

${ }^{108}$ Pienso, por ejemplo, en el litigante que con anterioridad en el pleito promovió un incidente similar y lo perdió. Esta circunstancia objetiva servirá de parámetro para que el juez pueda determinar si se actuó de mala fe en el nuevo incidente promovido. O también el litigante que propone la práctica de una prueba que no efectúa y luego intenta promoverla nuevamente.

109 Vale aquí entonces lo sustentado por Cachón: "Las actuaciones contrarias a la buena fe procesal constituyen una especie dentro del género, más amplio, de actuaciones contrarias al ordenamiento jurídico (...) Mientras toda actuación contraria a la buena fe es por definición contraria al ordenamiento jurídico, 


\section{c) La buena fe procesal se presume}

La buena fe procesal, al igual que la buena fe sustantiva, se presume y, por tanto, deberá existir una mínima actividad probatoria para su acreditación. ${ }^{110}$ No se pide acreditar un elemento subjetivo, es decir, no hay que probar que el litigante actuó con la intención de causar un daño a un tercero o al proceso. Serán las circunstancias objetivas del caso las que servirán para determinar si hubo mala fe en la actuación concreta. De igual forma, la presunción de buena fe procesal no excluye la posibilidad de que el legislador pueda, excepcionalmente, presumir iuris tantum la mala fe, para supuestos que deben estar rigurosamente tipificados.

De la presunción de la actuación conforme a la buena fe procesal se debe colegir la exigencia de una fuerte motivación tanto probatoria como jurídica de la resolución que imponga la sanción. ${ }^{11}$ La imprecisión y vaguedad del concepto de buena fe procesal coloca a la exigencia de la motivación en un plano superior al de cualquier otra resolución incidental. Luego, como la configuración de un acto como contrario a la buena fe procesal supone la existencia de prueba, la motivación debe alcanzar a todas las cuestiones probatorias, en especial a la determinación de los elementos objetivos de los cuales el juez extrae la mala fe procesal.

Desde luego que una buena motivación de la resolución traerá aparejadas ventajas colaterales innegables. Sin duda la motivación, junto con descartar la arbitrariedad en la aplicación del concepto, permitirá ir conformando jurisprudencialmente supuestos típicos de mala fe procesal capaces de universalizarse ${ }^{112}$, creando grados de certeza en la aplicación de la noción y delineando al menos el núcleo del concepto.

En este sentido, el Art. 8 inciso $3^{\circ}$ del Proyecto contempla expresamente la exigencia de motivación en la resolución que impone la sanción, exigencia que debería ser respetada íntegramente por cada juez o tribunal.

Esta exigencia de motivación debería ser precedida de la aplicación del principio de contradictorio y defensa, en el sentido de que el juez debe conferir a las partes la posibilidad de ser escuchadas y de defenderse de la imputación que al respecto se haga. ${ }^{113}$

no toda actuación procesal antijurídica puede ser considerada contraria a la buena fe. Por ende, el carácter antijurídico de la actuación procesal es una condición necesaria pero no suficiente para que una actuación o acto pueda ser sancionado". Para que dicha actuación pueda ser considerada contraria a la buena fe procesal es necesario que concurran ciertas características y situaciones en virtud de las cuales el legislador considere que la dicha actuación es merecedora de la sanción procesal, cuya catalogación exhaustiva resulta tan imposible como la misma idea de cerrar herméticamente el concepto de buena fe. Cachón Cárdenas, Manuel, "La buena fe en el proceso civil”, op. cit., p. 247.

110 Vid., Picó i Junoy, J., "El debido proceso 'leal'. Reflexiones en torno al fundamento constitucional del principio de buena fe procesal”, op. cit., p. 171, y Cachón, M., "La buena fe en el proceso civil”, op. cit., p. 245 .

111 Vid., Cachón, M., "La buena fe en el proceso civil”, op. cit., p. 245.

112 Vid., Picó i Junoy, J., El principio de la buena fe procesal, op. cit., pp. 71 y 72.

113 Este punto ha sido prácticamente afirmado por toda la doctrina comparada que impone la necesidad de establecer una necesaria contradicción y audiencia previa para la imposición de sanciones por actuaciones 
Por ende, como se trata de la aplicación de una sanción debería abrirse un incidente en el pleito, cuestión que no aparece recogida en el Proyecto.

\section{d) El recurso a la utilización de la buena o mala fe procesal}

La última reflexión que quiero efectuar está destinada a prevenir los peligros que implica abordar de manera irresponsable la temática de la buena fe procesal. Si este tema no es abordado con la suficiente seriedad, se corre el riesgo de diluirlo en la nada, sin ninguna implicancia práctica real. Y este esfuerzo corresponde principal y esencialmente a los jueces. En efecto, no será novedad entender que la buena fe procesal será un lugar común en toda la argumentación que hagan los abogados en defensa de los intereses de sus clientes. No es de extrañar entonces que todo incidente promovido, toda diligencia solicitada, todo recurso interpuesto, etc., será calificado por alguno de los litigantes como "contrario a la buena fe procesal", como un "claro ejemplo del ánimo dilatorio que tiene la contraparte", en fin, como un acto que "atenta contra nuestro principio fundamental de la buena fe procesal".

El peligro viene precisamente de la respuesta que el órgano jurisdiccional dé o deje de dar al emplazamiento que hace el litigante. En este sentido, creo que es un deber del juez que ha sido emplazado por una de las partes pronunciarse de manera motivada acerca de si un acto es contrario o no a la buena fe procesal. Es indispensable que el juez cuando considere que una actuación o conducta ha sido ejecutada de mala fe imponga las sanciones que el ordenamiento establece y no deje a la noción ya mencionada en un simple recurso argumentativo. Este tipo de prácticas traen aparejado un grave problema, dado que genera un peligroso mensaje de decir que la buena o mala fe de una conducta es irrelevante. ${ }^{114}$ Si el juez determina que una de las partes actuó de mala fe debe imponer las sanciones.

\section{Conclusiones}

- La buena fe procesal es concepto jurídico indeterminado, con el que se pretende moralizar las conductas humanas e introducir reglas morales, éticas y sociales al ámbito procesal.

- Siguiendo a la doctrina, se debe entender por buena fe procesal aquella conducta exigible a toda persona, en el marco de un proceso, por ser socialmente admitida como correcta.

- La buena fe es un concepto que hasta el momento permanece algo ajeno al proceso civil, sin que exista una norma general que imponga a las partes la necesidad de adecuar su conducta a la buena fe procesal.

contrarias a la buena fe procesal. Vid., por todos: Picó i Junoy, J., "El debido proceso 'leal'. Reflexiones en torno al fundamento constitucional del principio de buena fe procesal”, op. cit., p. 172.

${ }^{114}$ Vid., Cachón, M., "La buena fe en el proceso civil", op. cit., p. 244. 
- La doctrina ha discutido arduamente la posibilidad de extender la fórmula normativa general de actuación de buena fe a las alegaciones fácticas de las partes o al derecho de defensa, a través del deber de veracidad y completitud, y el de colaboración.

- Una parte de la doctrina sostiene que el deber de actuar conforme a la buena fe procesal lleva consigo el de ser veraces y completos en la narración de los hechos, además el de colaborar con el proceso para los fines de la justicia.

- Para otra parte de la doctrina los deberes de veracidad y completitud no pueden ser una emanación directa del principio de buena fe procesal.

- La buena fe procesal por tener un rango meramente legal no puede servir para limitar un derecho fundamental de corte procesal.

- El derecho a la tutela judicial efectiva y el derecho a defensa de los litigantes que no tienen el deber de actuar de buena fe no pueden fundamentar una limitación al derecho a defensa del litigante que debe observar el deber.

- El proceso civil chileno no debería reconocer los deberes procesales de veracidad y completitud, como tampoco un pretendido deber de colaboración procesal.

- Las garantías del contradictorio, defensa jurídica y el principio dispositivo sirven de pretexto para negar la posibilidad de actuar deberes positivos como los ya señalados. Además éstos no se condicen con un proceso civil que encuentra su estructura en base a las cargas y no a deberes.

- Por último, es necesario reemplazar o sustituir el concepto de buena fe procesal por la prohibición de actuar de mala fe. Se deben exigir a las partes ciertos comportamientos negativos, de mera abstención o prohibición, fundados en la proscripción de la mala fe.

\section{BiBLIOGRAFÍA}

Aguiar de Luque, Luis, "Los límites de los derechos fundamentales", en Revista del Centro de Estudios Constitucionales, No 14, 1993, pp. 9 a 34.

Aldunate Lizana, Eduardo, "La colisión de derechos fundamentales", en Revista Derecho y Humanidades, $\mathrm{N}^{\circ} 11,2005$, pp. 69 a 78.

Böckenförde Ernst, Wolfgang, Escritos sobre Derechos Fundamentales, Editorial Nomos, Baden-Baden, 1993.

Bordalí Salamanca, Andrés, "El debido proceso civil", en La constitucionalización del Derecho Chileno, Universidad Austral de Chile, Editorial Jurídica de Chile, 2003, pp. 251 a 295.

- "El derecho fundamental de acción: un intento de configuración en el orden constitucional chileno", en Revista de Derecho y Jurisprudencia, Tomo XCVII, No 3, 2000, pp. 81 a 105.

- $\quad$ "El modelo chileno de jurisdicción constitucional de las libertades. Análisis en el marco de los valores de seguridad jurídica e igualdad constitucional", en Revista de Derecho Universidad Austral de Chile, Vol. 18, No 1, julio, 2005, pp. 89 a 117.

Bove, Mauro. “Art. 111 Cost. E 'Giusto processo civile'”, en Rivista di Diritto Processuale Civile, año LVII ( $2^{a}$ serie), $N^{\circ} 2$, abril-junio 2002, pp. 479 a 522.

Brage Camazo, Joaquín, Los límites a los derechos fundamentales, Dykinson, Madrid, 2004. 
Cachón Cárdenas, Manuel, "La buena fe en el proceso civil", en El abuso del proceso: mala fe y fraude de ley procesal, Cuadernos de Derecho Judicial, CGPJ, Madrid, 2006, pp. 211 a 249.

Calamandrei, Piero, "Il processo come gioco", en Rivista di Diritto Processuale, Vol. V, parte I, 1950 , pp. 23 a 51.

- Derecho Procesal Civil, tomo III, traducción de Santiago Sentis Melendo, Ejea, Buenos Aires, 1986.

Calogero, Guido, "Probità, lealtà, veracità nel processo civile", en Rivista di Diritto Processuale Civile, Vol. XVI, parte I, 1939, pp. 129 a 153.

Cappelletti, Mauro, "Ideologías en el proceso civil”, en Proceso, Ideología y Sociedad, Ediciones Jurídicas Europa-América, traducción de Santiago Sentis Melendo y Tomás Banzhaf, p. 15.

- El testimonio de la parte en el sistema de oralidad. Contribución a la teoría de la utilización probatoria del saber de las partes en el proceso civil. Primera parte, traducción de Tomás Banzhaf, Librería Editora Platense, La Plata, 2002.

Carnelutti, Francesco, "Líneas generales de la reforma del proceso civil de cognición", en Estudios de Derecho Procesal, Vol. I, traducción de Santiago Sentis Melendo, Ediciones Jurídicas Europa-América, Buenos Aires, 1952, pp. 63 a 175.

Carretta, Francesco, "Deberes procesales de las partes en el proceso civil chileno: referencia a la buena fe procesal y al deber de coherencia”, en Revista de Derecho Universidad Austral de Chile, Vol. XXI, No 1, julio, 2008, pp. 101 a 127.

Cipriani, Franco, “El abogado y la verdad”, en Revista del Poder Judicial, No 72, 2003, pp. 175 a 181.

Comoglio, Luigi Paolo, "El Il comma dell'art. 24. Il diritto di difesa nel processo civile", en Commentario della Costituzione. Rapporti Civile, a cura de Giuseppe Branca, Nicola Zanichelli Editore, Bolonia, 1988, pp. 53 a 81.

Condorelli, Epifanio, Del abuso y la mala fe dentro del proceso, Abeledo Perrot, Buenos Aires, 1986.

Cordón Moreno, Faustino, "El derecho a obtener la tutela judicial efectiva", en Derechos Procesales Fundamentales, CGPJ, Madrid, 2005, pp. 215 a 243.

Cortés Domínguez, Valentín, "Algunos aspectos sobre la inversión de la carga de la prueba", en Revista de Derecho Procesal Iberoamericana, Nos. 2-3, 1972, pp. 581 a 642.

De Bartolomé Cenzano, José Carlos, Derechos fundamentales y libertades públicas, Tirant lo Blanch, Valencia, 2003.

Díez-Picazo Jiménez, Ignacio, et al., El derecho a la tutela judicial y el recurso de amparo. Una reflexión sobre la jurisprudencia constitucional, Civitas, Madrid, 1995.

Díez-Picazo, Luis, Sistema de derechos fundamentales, segunda edición, Civitas, Madrid, 2005.

Fernández López, Mercedes, La carga de la prueba en la práctica judicial civil, Editorial La Ley, Madrid, 2006.

Ferrer Beltrán, Jordi, Prueba y verdad en el Derecho, Editorial Marcial Pons, Madrid, 2002.

García Solá, Marcela, "De la necesidad de compatibilizar en el proceso el principio del 'abuso del derecho' con la garantía de defensa en juicio”, en Abuso Procesal, Peyrano J., director, Editorial Rubinzal-Culzoni, Buenos Aires, 2001, pp. 211 a 223.

Gimeno Sendra, Vicente, "Análisis crítico de la Ley de Enjuiciamiento Civil”, en Revista Jurídica Española de Doctrina, Jurisprudencia y Bibliografía, No 2, 2007, pp. 1891 a 1896.

Gisbert Pomata, Marta, "La estafa procesal en el proceso civil: su apreciación por los tribunales”, en Revista de Derecho Procesal, Nos. 1-3, 2004, pp. 293 a 327.

Goig Martínez, Juan Manuel, et al., Dogmática y práctica de los derechos fundamentales, Tirant lo Blanch, Valencia, 2006. 
Goldschmidt, James, Teoría general del proceso, Editorial Labor, Barcelona, 1936.

González Granda, Piedad, "Los criterios de disponibilidad y facilidad probatoria en el sistema del artículo 217 de la LEC", en Carga de la prueba y responsabilidad civil, Tirant lo Blanch, Valencia, 2007, pp. 29 a 74.

- La nueva ley de enjuiciamiento civil, Tomo I, Cortés Domínguez y Moreno Catena (coord.), editorial Tecnos, Madrid, 2000.

Grasso, Eduardo, "La collaborazione nel processo civile", en Rivista di Diritto Processuale, Vol. XXI, 1996, pp. 580 a 609.

Grossmann, Kaethe, "El deber de veracidad de las partes litigantes en los juicios civiles. Exposición de Derecho Comparado", en Jurisprudencia Argentina, tomo 71, Buenos Aires, 1940, pp. 9 a 24.

Jiménez BAutista, Susana, "La buena fe, perspectiva doctrinal, legal y jurisprudencial. Examen del artículo 247 de la vigente Ley de Enjuiciamiento Civil”, en Revista Jurídica Española de doctrina, jurisprudencia y bibliografía, La Ley, $\mathrm{N}^{\circ}$ 4, 2003, pp. 1557 a 1565.

Liebman, Enrico Tullio, Manuale di diritto processuale civile, Principi, Giuffrè Editore, Milán, 1992.

Lozano-Higuero, Manuel, "La buena fe procesal: consideraciones doctrinales y jurisprudenciales", en El abuso del proceso: mala fe y fraude de ley procesal, Consejo General del Poder Judicial, Madrid, 2006, pp. 41 a 102.

- $\quad$ "La probidad en el nuevo proceso civil (Respecto a las reglas de la buena fe procesal. Multas por su incumplimiento)", en Revista Vasca de Derecho Procesal y Arbitraje, tomo XIV, 2002, pp. 321 a 339.

Marchetti, Claudio, "Dolo revocatorio e falsa alegazione", en Rivista di Diritto Processuale, Vol. XV, 1960, pp. 418 a 445.

Maturana, Cristián: "Los principios que deben regir un nuevo proceso civil en Chile", en Hacia una Nueva Justicia Civil, Boletín Jurídico del Ministerio de Justicia, $\mathrm{N}^{\circ} 7$, año 4, 2005 , pp. 9 a 20.

Micheli, Gian Antonio, Curso de derecho procesal civil, Vol. I, Parte general, traducción de Santiago Sentis Melendo, Ediciones Jurídicas Europa-América, Buenos Aires, 1970.

- La carga de la prueba, traducción de Santiago Sentis Melendo, Editorial Temis, Bogotá, 2004.

Montero Aroca, Juan, "Ideología y proceso civil. Su reflejo en la buena fe procesal”, en El abuso del proceso: mala fe y fraude de ley procesal, Consejo General del Poder Judicial, Madrid, 2006, pp. 251 a 320.

- Derecho Jurisdiccional II, Proceso Civil, décima edición, Tirant lo Blanch, Valencia, 2001.

Moreno Catena, Víctor, et al., Derecho procesal civil, Tomo I, Vol. I, parte general, sexta edición, Tirant lo Blanch, Valencia, 1992.

Moreno García, Antonio, "La buena fe y derechos fundamentales en la jurisprudencia del Tribunal Constitucional”, en Revista Española de Derecho Constitucional, No 38, año 13, 1993 , pp. 263 a 295.

Naranjo de la CRUz, RAFAel, Los límites de los derechos fundamentales en las relaciones entre particulares: la buena fe, Centro de Estudios Políticos y Constitucionales, Madrid, 2000.

NúÑEZ, RAúl, "Crónica sobre la reforma del sistema procesal civil chileno (Fundamentos, historia y principios), en Revista de Estudios de la Justicia, No 6, 2005, pp. 175 a 189.

Palacios, Lino, Manual de Derecho Procesal Civil, LexisNexis, decimoséptima edición, Buenos Aires, 2003.

Picardi, Nicola, "Il principio del contraddittorio", en Rivista di Diritto Processuale, año LII, $\mathrm{N}^{\circ} 3,1998$, pp. 673 a 681. 
Picó i Junoy, JoAn, “Aproximación al principio de buena fe procesal en la nueva ley de enjuiciamiento civil”, en Revista Jurídica de Catalunya, No 4, 2001, pp. 947 a 968.

- $\quad$ "El debido proceso 'leal'. Reflexiones en torno al fundamento constitucional del principio de buena fe procesal", en Justicia, Revista de Derecho Procesal, Nos 3-2, 2004, pp. 143 a 181.

- El principio de la buena fe procesal, Bosch Editor, Barcelona, 2003.

- Las garantías constitucionales del proceso, Bosch, Barcelona, 1997.

Prieto Castro, Leonardo, "Ética procesal. Valoración de la conducta de las partes”, en Estudios y comentarios para la teoría y la práctica del proceso civil, Vol. I, Editorial Reus, Madrid, 1950, pp. 140 a 143.

Proto Pisani, Andrea, Lezioni di diritto processuale civile, Jovene Editore, tercera edición, Nápoles, 1999.

Romero Seguel, Alejandro, "Comentario a la sentencia de la Corte de Suprema de 9 de mayo de 2001. El principio de la buena fe procesal y su desarrollo en la propia jurisprudencia, a la luz de la doctrina de los actos propios", en Revista Chilena de Derecho, Vol. 30, No 1 , 2003, pp. 167 a 172.

Satta, Salvatore, Diritto Processuale Civile, Cedam, Padova, 1948.

Scarselli, Giuliano, "Lealtà e probità degli atti processuali", en Rivista Trimestrale di Diritto e Procedura Civile, No 1, año LII, 1998, pp. 91 a 148.

Sentis Melendo, Santiago, "Fuentes y medios de prueba", en La prueba. Los grandes temas del derecho probatorio, Ediciones Jurídicas Europa-América, Buenos Aires, 1979, pp. 141 a 172.

Serra, Manuel, "Liberalización y socialización del proceso civil", en Revista de Derecho Procesal Iberoamericana, $\mathrm{N}^{\text {os. }} 2-3,1972$, pp. 511 a 543.

Silva Melero, Valentín, "El llamado deber de decir verdad en el proceso civil", en Revista General de Legislación y Jurisprudencia, tomo 188, año 85, Madrid, 1936, pp. 718 a 734.

Trocker, Nicolo, "Il nuovo articolo 111 della costituzione e il 'giusto procceso' in materia civile: profili generali”, en Rivista Trimestrale di Diritto e Procedura Civile, año LV, 2002, pp. 381 a 410 .

Vallejos, Juan, "El abuso del proceso en materia probatoria", en XXI Congreso Nacional de Derecho Procesal, Tomo I, Universidad Católica del Cuyo, San Juan, 2001, pp. 731 a 742.

Vallote, Daniel, "Abuso del proceso por las partes, presupuestos generales", en XXI Congreso Nacional de Derecho Procesal, Tomo I, Universidad Católica del Cuyo, San Juan, 2001, pp. 267 a 285.

Zeiss Walter, El dolo procesal. Aporte a la precisión teórica de una probibición del dolo en el proceso de cognición civilístico, Ediciones Jurídicas Europa-América, traducción de Tomás A. Banzhaf, Buenos Aires, 1979. 